\title{
The Inherent Power of Common Law Courts to Provide Assistance in Cross-Border Insolvencies: From Comity to Complexity
}

\author{
Andrew Godwin* \\ Timothy Howse** \\ Ian Ramsay***
}

\begin{abstract}
The weighty and difficult issues associated with cross-border insolvency have generated considerable debate over the last two decades. Legislative reform has typically proven slow and fragmented. This article analyses the inherent power of common law courts to grant assistance in cross-border insolvency proceedings and the basis on which the inherent power is exercised. In doing so, it seeks to explore how the inherent power may continue to be of utility to common law courts. In particular, it considers the position in jurisdictions that are yet to adopt the UNCITRAL Model Law or enact a substantial statutory regime for recognising and cooperating with foreign courts or representatives in insolvency proceedings. The article considers the benefits and disadvantages of continuing to recognise - and extend the inherent power. It suggests that although there are fundamental differences concerning the exercise of the inherent power, it may be possible to agree on a number of principles that inform the application of the inherent power and its future development.
\end{abstract}

\section{Introduction}

'The extent of the extra-statutory powers of a common law court to assist foreign liquidators is a very tricky topic on which the Board, the House of Lords and the Supreme Court have not been conspicuously successful in giving clear or consistent guidance.' Lord Neuberger in Singularis Holdings Limited $v$ Pricewaterhouse Coopers [2014] UKPC 36 [154]

The "weighty and difficult" issues associated with cross-border insolvency (CBI) have generated considerable debate over the last two decades. Legislative reform has typically proven slow and fragmented. It is also an area where 'the ordinary principles of private international law, developed in the context of ordinary civil proceedings taking place between

\footnotetext{
* Associate Professor, Melbourne Law School, The University of Melbourne. E-mail: $<$ a.godwin@unimelb.edu.au>.

** Legal Advisor, Linklaters LLP, London. E-mail: <t.howse@pgrad.unimelb.edu.au>.

*** Harold Ford Professor of Commercial Law, Melbourne Law School, The University of Melbourne. E-mail: $<$ i.ramsay@unimelb.edu.au>.

${ }^{1}$ CCIC Finance Ltd v Guangdong International Trust \& Investment Corp \& Guangdong International Trust and Investment Corp Hong Kong (Holdings) Ltd (Garnishee) [2005] HKEC 1180 [93].
}

This is the author manuscript accepted for publication and has undergone full peer review but has not been through the copyediting, typesetting, pagination and proofreading process, which may lead to differences between this version and the Version of Record. Please cite this article as doi: 10.1002/iir.1267 
individuals, are often inapt in the context of collective insolvency proceedings. ${ }^{2}$ While CBI would ideally be addressed according to a universally accepted convention, the significant divergences in approach taken by different jurisdictions make this a remote aspiration.

The assistance that may be provided by a local court to either a foreign insolvency representative or a foreign court is a critical aspect of any CBI regime. The provision of assistance to foreign courts or insolvency representatives is necessary to reduce the cost and inconvenience associated with concurrent insolvency proceedings. Jurisdictions often provide multiple gateways to facilitate assistance in CBI matters. Many jurisdictions have adopted the United Nations Commission on International Trade Law (UNCITRAL) Model Law on Cross Border Insolvency (the 'Model Law').

Alongside the various statutory mechanisms, the inherent power of common law courts to provide assistance in insolvency matters is one of the gateways through which assistance may be provided. The last two decades have seen significant differences of opinion on the extent and proper application of the inherent power of common law courts to provide assistance in insolvency proceedings. Following Lord Hoffmann's controversial statements concerning the 'golden thread of insolvency law' - namely, 'modified universalism' - in the watershed case of $H I H$ Insurance, ${ }^{3}$ the highest courts of England have consistently differed on the limits of the inherent power. Recent English cases have seen a refinement of the power, but have also caused considerable confusion and raised additional questions about the scope and continuing utility of the power.

This article analyses the inherent power of common law courts to grant assistance in CBIs and the basis on which it is exercised. In doing so, it seeks to explore how the inherent power may continue to be of utility to common law courts. In particular, it considers the position in Singapore and Hong Kong, where the issues are especially relevant given that neither jurisdiction has yet adopted the UNCITRAL Model Law or enacted a substantial statutory regime for recognising and cooperating with foreign courts or representatives in insolvency proceedings. ${ }^{4}$

\footnotetext{
2 Tom Smith QC, 'Recognition of Foreign Corporate Insolvency Proceedings at Common Law' in Richard Sheldon QC (ed), Cross-Border Insolvency (4th edition, Bloomsbury Professional, 2015) 6.1.

${ }^{3}$ Re HIH Casualty and General Insurance Ltd [2008] 1 WLR 852.

${ }^{4}$ At the time of writing, Singapore is on course to adopt the UNCITRAL Model Law pursuant to a package of reforms designed to strengthen the legal framework for debt restructuring in Singapore. See Singapore Ministry of Law, Public Consultation on Proposed Amendments to the Companies Act to Strengthen Singapore as an International Centre for Debt Restructuring', available at:

$<$ https://www.mlaw.gov.sg/content/minlaw/en/news/public-consultations/public-consultation-on-proposedamendments-to-the-companies-act-.html>. Until the proposed legislation comes into effect, as noted by the Report of the Insolvency Law Review Committee in relation to Singapore, 'Section 151 of the Bankruptcy Act permits the High Court to act in aid of and be auxiliary to the courts of Malaysia as well as the courts of any other designated country with jurisdiction in bankruptcy and insolvency matters, provided these courts are required to act in aid of an be auxiliary to the courts in Singapore. However, no other country other than Malaysia has thus far been designated under this provision': Report of the Insolvency Law Review Committee, 'Final Report' (2013) 225.
} 
The structure of this article is as follows: Part II defines the inherent power of courts to grant assistance in CBIs and explores its origins by considering the early cases that have shaped the power's development. Part III explores the question - what factors influence the existence and scope of the power? Part IV considers the principal circumstances in which courts have exercised the power and the nature of the assistance that they have provided. Part V outlines the circumstances in which the courts have declined to exercise the power. Part VI analyses the continuing utility of the inherent power. For this purpose, it considers where the current balance of authority sits, the policy arguments in favour and against continuing to recognise the inherent power as an available gateway, and finally, suggests the relevant principles that should be applied in exercising the inherent power. Part VII concludes.

\section{What is the power and its origins?}

Most common law jurisdictions recognise an inherent power for courts to provide assistance to other courts or relevant parties during the course of insolvency proceedings. This Part considers the historical importance of 'comity' to modern CBI law, the leading early cases that recognised the power to provide 'assistance', the relevance of the 'ancillary liquidation doctrine' and, finally, the ongoing relevance of the power in the $21^{\text {st }}$ century.

\section{A Early bankruptcy cases and comity}

The modern-day manifestation of the inherent power can, in part, be traced to bankruptcy proceedings dating 'as far back as the mid eighteenth century. ${ }^{, 5}$ The 1764 case of Solomons $v$ Ross $^{6}$ saw the English courts 'prepared to recognise the extra-territorial effects of a foreign bankruptcy in England, so as to require creditors based in England to prove in the foreign bankruptcy. ${ }^{, 7}$ Crystal notes that this "was perhaps the earliest recognition of the principle of universalism'.

Writing in 1947, Nadelmann described Solomons $v \operatorname{Ross}^{9}$ as 'the leading case on the effect in England of bankruptcy declared abroad. ${ }^{10}$ The case saw 'trustees in bankruptcy appointed in Amsterdam... allowed to collect assets in England which had been garnished by an English

\footnotetext{
${ }^{5}$ Ian Fletcher, 'Cross-border Cooperation in Cases of International Insolvency: Some Recent Trends Compared' (1991-2) 6-7 Tulane Civil Law Forum 171, 182.

6 (1764) 1 HBI 131.

7 Michael Crystal, 'The Golden Thread: Universalism and Assistance in International Insolvency' (2011) [13], available at: <http://www.jerseylaw.je/Publications/JerseyLawReview/feb11/JLR1102_Crystal.aspx\#_ftn6>.

${ }^{8}$ Ibid [13]. Universalism is discussed in greater detail in Part III.

${ }^{9}$ (1764) 1 HBI 131. The case was reported in a footnote in Blackstone's Report in Folliott v Ogden (1789) $1 \mathrm{H}$ B1 123. The case received negative treatment in Galbraith $v$ Grimshaw [1910] AC 508, 511, where Lord Loreburn stated: 'I am not prepared to act upon the case which is scantily reported in the volume of Blackstone's Reports.'

${ }^{10}$ Kurt Nadelmann, 'Solomons v Ross and International Bankruptcy Law' (1947) 9 Mod LR 154, 154.
} 
creditor shortly before the trustees were appointed in Amsterdam. ${ }^{11}$ Interestingly, ' $[\mathrm{b}] \mathrm{y}$ what reasoning the Court reached its decision remains a matter of conjecture.' So too was the 'theory [by which] the Court recognised that power. ${ }^{\text {, }}$

Nevertheless, subsequent references to Solomons $v$ Ross considered it as supporting the idea of 'comity of nations'. Solomons v Ross was, for example, cited in support of the following proposition in Alivon v Furnival in 1834:

'The property in the effects of the bankrupt does not appear to be absolutely transferred to these [French] syndics in the way that those of a bankrupt are in this country; but it should seem that the syndics act as mandatories or agents for the - creditors; the whole three or any two or one of them having the power to sue for and recover the debts in their own names. This is a peculiar right of action, created by the law of that country; and we think it may by the comity of nations be enforced in this, as much as the right of foreign assignees or curators, or foreign corporations, appointed or created in a different way from that which the law of this country requires. 13

Along similar lines, most transnational bankruptcies in the United States were historically based on the judicial concept of comity, which has been described as 'the deference of one nation to the legislative, executive, and judicial acts of another - not as an obligation, but as a courtesy serving international duty and convenience. ${ }^{14}$ The Encyclopaedic Australian Legal Dictionary defines 'comity' as a 'concept according to which the courts of one state respect the rules, customs, and laws of another state, whether by acts of restraint... or by acts of cooperation " 15

The rationale of comity, as it relates to CBI, was considered in Cunard Steamship Co Ltd v Salen Reefer Services $A B^{16}$ - to '[enable] the assets of a debtor to be dispersed in an

\footnotetext{
${ }^{11}$ Ibid 154.

${ }^{12}$ Ibid 160.

${ }^{13}$ Alivon v Furnival (1834) 149 ER 1084, emphasis added. See also the submissions of Sir Horace Davey QC and Kennedy QC (first name omitted in judgment) in Levasseur v Mason \& Barry Ltd [1891] 2 QB 73. Under French law, a syndic may operate as a bankruptcy trustee. A syndic is '[a]n agent or attorney who acts for a corporation or university': LexisNexis, Encyclopaedic Australian Legal Dictionary (at 1 February 2016) Syndic, 'SY'.

14 David Farmer, 'Chapter 15 Ancillary and Other Cross-Border Insolvency Cases' (2015) 19 Hawaii Bar Journal 14, 16-7. This was similarly the position in Canada for recognising foreign judgments: see Scott Bomhof and Adam Slavens, 'Shifting Gears in Cross-Border Insolvencies: From Comity to COMI' (2008) 24 Banking and Finance Law Review 31.

${ }^{15}$ LexisNexis, Encyclopaedic Australian Legal Dictionary (at 1 December 2015) Comity, 'CO'. For a wellknown US case that discusses the concept of comity in the context of the recognition and enforcement of foreign judgments, see Hilton v. Guyot 159 U.S. 113 (1895). See also William S. Dodge, 'International Comity in American Law' (2015) 115 Columbia Law Review 2071 (discussing international comity in American law generally).

${ }_{16} 773 \mathrm{~F} 2 \mathrm{~d} 452$ at $457-458$ (1985).
} 
equitable, orderly and systematic manner, rather than in a haphazard, erratic or piecemeal fashion. ${ }^{17}$ Indeed, prior to the enactment of the Model Law, the US courts relied on a 'subjective, comity-based process' in recognising and providing relief to parties in foreign insolvency proceedings. ${ }^{18}$ Chapter 15 of the United States Bankruptcy Code, in which the Model Law was enacted, now sets out the relevant process for recognition but still allows 'principles of comity [to] come into play" ${ }^{19}$ for the purposes of determining additional assistance under $\$ 1507 .{ }^{20}$ This is consistent with the US approach of making Chapter 15 'the exclusive door to ancillary assistance to foreign proceedings.'21

In Canada, prior to the introduction of the Model Law and other statutory provisions, comity was... increasingly important in the bankruptcy context... [a]s internationalization increase[d]. ${ }^{22}$ New Zealand also placed significant reliance on the principles of comity in circumstances where its limited statutory scheme did not apply prior to its enactment of the Model Law. ${ }^{23}$ For example, comity was granted to Belgian courts in Turners \& Growers Exporters Ltd $v$ The Ship "Cornelis Verolme" ${ }^{, 4}$ in recognising a foreign administrator. ${ }^{25}$ In South Africa, the common law approach to recognising CBI proceedings also appears to have

\footnotetext{
${ }^{17}$ Ibid.

${ }^{18}$ Re Bear Stearns High-Grade Structured Credit Strategies Master Fund Ltd, 389 B.R. 325 (2007) 332.

19 Ibid 334.

${ }^{20}$ Title 11 - Bankruptcy (Pub L 95-598, title I, §101, Nov 6, 1978, 92 Stat. 2549). $§ 1507$ (b) provides:
}

'In determining whether to provide additional assistance under this title... the court shall consider whether such additional assistance, consistent with the principles of comity [emphasis added], will reasonably assure -

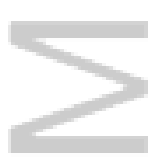

(1) just treatment of all holders of claims against or interests in the debtor's property;

(2) protection of claim holders in the United States against prejudice and inconvenience in the processing of claims in such foreign proceeding;

(3) prevention of preferential or fraudulent dispositions of property of the debtor;

(4) distribution of proceeds of the debtor's property substantially in accordance with the order prescribed by this title; and

(5) if appropriate, the provision of an opportunity for a fresh start for the individual that such foreign proceeding concerns.'

See also $\S 1509$ (b)(3), which provides that '[i]f the court grants recognition under section $1517 \ldots$ a court in the United States shall grant comity or cooperation to the foreign representative.'

${ }^{21}$ US House of Representatives, 'Bankruptcy Abuse Prevention and Consumer Protection Act of 2005: Report of the Committee on the Judiciary House of Representatives to accompany s 256 together with dissenting, additional dissenting and additional minority views' (109th Congress 1st Session, Report 109-31 Part 1, Union Calendar No 14, 8 April 2005) 110.

${ }^{22}$ Roberts v Picture Butte Municipal Hospital [1999] 4 WWR 443 [20].

${ }^{23}$ Paul Heath, 'International Insolvencies: A New Zealand Perspective' (1998) 6(2) Insolvency Law Journal 90, 94.

${ }^{24}$ [1997] 2 NZLR 110.

${ }^{25}$ Cf Fournier v The Ship "Margaret $Z$ " [1997] 1 NZLR 629, 639 where the principles of comity were held to 'not be relevant in this case [because] the master and crew [had] priority', thereby prioritising a local maritime wages lien claim over the 'principles of comity.' Justice Salmon noted that the 'asset will still be dispersed in an equitable, orderly and systematic manner.' 
been based on comity. ${ }^{26}$ Similarly, in Hong Kong the absence of a statutory framework has meant that CBI proceedings and assistance have been recognised on the basis of "comity of nations. ${ }^{27}$

But what does a grant of 'comity' entail, and to what extent does it constitute the doctrinal basis for the inherent power? It is clear that comity may require local courts to cooperate with foreign courts and assist foreign insolvency proceedings, either by acting in a positive sense or by refusing to act at all. However, the inherent power of common law courts to provide assistance does not appear to be synonymous with the often-vague dictates of comity.

The power also appears to be motivated by other imperatives. Whereas 'comity' in CBI proceedings suggests deference to the legislative, executive and judicial acts of another sovereign nation (often as a matter of respect), the inherent power does not appear to be obviously derived from any need to respect a sovereign nation. Instead, it would appear to be more heavily influenced by the theory of modified universalism as discussed in Part IIIA below, and, indeed, by considerations concerning the fundamental nature of insolvency proceedings.

\section{B African Farms and Cambridge Gas}

In part, the modern-day manifestation of the inherent power of common law courts to provide assistance can be traced back to the South African case of African Farms ${ }^{28}$ - a case that over a century later caused a sharp division of opinion in the House of Lords after being invoked in Cambridge Gas. $^{29}$

African Farms Ltd was an English company with substantial assets in the Transvaal - a former province in north-eastern South Africa - and was in liquidation in England. As noted by Lord Sumption in Singularis: 'There was no power to wind it up in the Transvaal because the number of members had fallen below the minimum required to qualify it as a 'company' for the purpose of the statutory power of winding up [in the Transvaal]. ${ }^{30}$

Chief Justice Innes, the presiding judge in African Farms, noted that there was no statutory power to assist with the liquidation. His Honour famously stated that 'recognition... carries with it the active assistance of the Court...' Such recognition entailed:

\footnotetext{
26 INSOL, 'Cross-Border Insolvency: South Africa' 188, available at: <www.insol.org/pdf/cross_pdfs/South\%20Africa.pdf>.

${ }^{27}$ See, for example, Re Irish Shipping Ltd [1985] HKLR 437, 445, where Justice Jones noted: 'Another factor that I have taken into account in exercising my discretion is the comity of nations whereby it is desirable that the court should assist the liquidator in another jurisdiction to carry out his duties unless good reasons to the contrary have been put forward and I find none in this case.'

${ }^{28}$ In re African Farms Ltd [1906] TS 373, 377.

${ }^{29}$ Cambridge Gas Transport Corp v Official Committee of Unsecured Creditors of Navigator Holdings Plc [2006] UKPC 26; [2007] 1 AC 508; [2006] BCC 962.

${ }^{30}$ Singularis Holdings Limited (Appellant) v PricewaterhouseCoopers (Respondent) [2014] UKPC 36 [13] (per Lord Sumption).
} 
'A declaration, in effect, that the liquidator is entitled to deal with the Transvaal assets in the same way as if they were within the jurisdiction of the English courts, subject only to such conditions as the Court may impose for the protection of local creditors, or in recognition of the requirements of our local laws. ${ }^{31}$

Further, the deleterious effects of multiple insolvency proceedings and the destruction of value were recognised:

'If we are able... to recognise and assist the liquidator, then I think we should do so; because in that way only will the assets here be duly divided and properly applied in - satisfaction of the company's debts. If we cannot do so, then this result follows, that the directors cannot deal with the property here, and that the liquidator cannot prevent creditors seizing it in execution of their judgments. Unnecessary expenses will be incurred, and the estate will be left to be scrambled for among those creditors who are in a position to enforce their claims. ${ }^{32}$

Importantly, the 'active assistance of the court' was not expressly regarded as a matter of comity. Recognition was instead warranted on the basis that the global insolvency proceedings would be frustrated if assistance was not provided. Implicit in this approach is an underlying assessment about the nature of cross-border insolvency proceedings - namely, that they are universal in nature.

The African Farms decision was considered 100 years later in the modern leading cases of Cambridge Gas, HIH, Rubin and Singularis. These cases have largely shaped the current debate concerning the inherent power.

The Privy Council decision of Cambridge Gas concerned the insolvency of an Isle of Man company under Chapter 11 of the US Bankruptcy Code and the approval by the US Bankruptcy Court of a plan of reorganisation under which the shares of the company were vested in the representative of the creditors of the company. ${ }^{33}$ Lord Hoffmann, delivering judgment on behalf of the court, identified the universal nature of bankruptcy proceedings:

'The English common law has traditionally taken the view that fairness between creditors requires that, ideally, bankruptcy proceedings should have universal application. There should be a single bankruptcy in which all creditors are entitled and

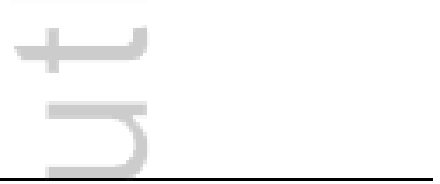

\footnotetext{
${ }^{31}$ In re African Farms Ltd [1906] TS 373, 377.

${ }^{32}$ Ibid 377.

${ }^{33}$ See Tom Smith QC, 'Recognition of Foreign Corporate Insolvency Proceedings at Common Law' in Richard Sheldon QC (ed), Cross-Border Insolvency (4th edition, Bloomsbury Professional, 2015) 6.46.
} 
required to prove. No one should have an advantage because he happens to live in a jurisdiction where more of the assets or fewer of the creditors are situated. ${ }^{34}$

Citing African Farms with approval, Lord Hoffmann further explained that 'the underlying principle of universality [was] of equal application' to insolvency proceedings generally. ${ }^{35}$ This was despite the fact that 'the common law on CBI had for some time been "in a state of arrested development"،, due in large part to the operation of statutory provisions such as section 426 of the Insolvency Law Act $1986{ }^{36}$ This section establishes a procedure, amongst other things, for providing court assistance to insolvency proceedings in many of England's former colonies. Speaking with respect to the ability of a local court to provide assistance, Lord Hoffmann noted:

'At common law, their Lordships think it is doubtful whether assistance could take the form of applying provisions of the foreign insolvency law which form no part of the domestic system. But the domestic court must at least be able to provide assistance by doing whatever it could have done in the case of a domestic insolvency. The purpose of recognition is to enable the foreign office holder or the creditors to avoid having to start parallel insolvency proceedings and to give them the remedies to which they would have been entitled if the equivalent proceedings had taken place in the domestic forum. ${ }^{, 37}$

In determining the limits of assistance, the scope would be determined by statute where 'the statute specifies what the court must do. ${ }^{38}$ Conversely, subsequent cases have made it clear that the common law has a significant role to play where the statute does not directly instruct the court on the appropriate assistance it should provide. ${ }^{39}$

Thus, African Farms was endorsed in Cambridge Gas. It is important to note that the use of African Farms in Cambridge Gas and subsequent cases was heavily criticised by Lord Collins in Singularis. His Honour noted that 'too much had been read into [it]', that '[i]t was not mentioned in any English case until it was cited in argument in [1997]' and that '[i]t had never been mentioned in the classical company law texts. ${ }^{40}$

Lord Collins appears to be correct in stating that African Farms had fallen into obscurity in the UK for 100 years. It is worth, however, mentioning that it had been applied prior to Cambridge Gas in other jurisdictions. For example, courts in New Zealand recognised the

\footnotetext{
${ }^{34}$ Cambridge Gas Transport Corp v Official Committee of Unsecured Creditors of Navigator Holdings Plc [2006] UKPC 26; [2007] 1 AC 508; [2006] BCC 962 [16].

${ }^{35}$ Ibid [20].

${ }^{36}$ Ibid [18].

${ }^{37}$ Ibid [22] [emphasis added].

${ }^{38}$ Ibid [22].

${ }^{39}$ This is considered subsequently in the analysis in Parts IV and V below.

${ }^{40}$ Singularis Holdings Limited (Appellant) v PricewaterhouseCoopers (Respondent) [2014] UKPC 36 [55]. The case is considered in detail subsequently.
} 
African Farms principle in $1996 .{ }^{41}$ Similarly, in the 1998 South African case of Ward ${ }^{42}$ Scott JA cited African Farms and noted:

'When an external company is being wound up in the country of its incorporation a competent South African court will... on application and in the exercise of its discretion, grant an order recognising the foreign appointed liquidator and ordinarily by so doing declare the liquidator to be entitled to deal with local assets (subject, of course, to local law) as if those assets were situated in the country in question. Such an order will be founded not only upon considerations of comity, but also convenience and equity. ${ }^{43}$

The twin considerations of comity and convenience are consistent themes in the recognition of foreign insolvency proceedings, as the analysis in this article will show.

\section{The ancillary liquidation doctrine}

The origins of the power can also be found in the 'doctrine of ancillary liquidation'. The doctrine will be applicable where a local court determines that it is the 'ancillary' jurisdiction for the purposes of an insolvency, and that a foreign court is the appropriate forum to conduct the principal proceedings. As noted by Smart, ' $[\mathrm{t}]$ he most obvious and immediate purpose of an ancillary winding up is to secure assets within the jurisdiction of the... court and to prevent "two "full" liquidations... [that] may well result in not only increased costs but also disparity between the creditors in each country. 44

An early English case considering ancillary liquidation was In re Commercial Bank of South Australia, where North J considered the position of the English proceedings:

'I will say this, that I think the winding-up here will be ancillary to a winding-up in Australia, and, if I have the control of the proceedings here, I will take care that there shall be no conflict between the two Courts, and I shall have regard to the interests of all the creditors and all the contributories, and shall endeavour to keep down the expenses of the winding-up so far as is possible. ${ }^{45}$

The doctrine appears to have first been applied by English courts who, faced with the challenges of administering insolvencies across the Empire, needed to ensure that 'each

\footnotetext{
${ }^{41}$ Turners \& Growers Exporters Ltd v The Ship 'Cornelius Verolme’ [1997] 2 NZLR 110, 120.

${ }^{42}$ Ward and Another $v$ Suit and Others In Re: Gurr v Zambia Airways Corporation Ltd. (51/96) [1998] ZASCA 16; [1998] 2 All SA 479.

${ }^{43}$ Ibid. See also Moolman v Builders \& Developers (Pty) Ltd. (in Provisional Liquidation) (170/89) [1989] ZASCA 171.

44 Philip Smart, 'International Insolvency: Ancillary Winding up and the Foreign Corporation' (1990) 39 International and Comparative Law Quarterly 827, 828.

${ }^{45}$ In re Commercial Bank of South Australia (1886) 33 Ch 174.
} 
proceeding was universal' ${ }^{46}$ Colonial ancestry appears to continue to influence CBI statutes. England, for example, has a statutory cross-border assistance regime in s 426 of the Insolvency Law Act 1986 that expressly recognises its former colonies (i.e. Australia, New Zealand and Canada) and various other offshore financial centres. ${ }^{47}$

It is equally important to note that the inherent power may be exercised in the absence of ancillary liquidation proceedings, and that its exercise in such circumstances will 'depend on the nature of the assistance sought' ${ }^{48}$

\section{The power's relevance and the 'gateways' for judicial assistance}

In many jurisdictions, there are multiple gateways for resolving CBI matters. For example, the United Kingdom recognises four distinct gateways: the European Insolvency Regulation $;^{49}$ section 426 of the Insolvency Act 1986 covering 'relevant countries'; the UNCITRAL Model Law as adopted by the Cross-Border Insolvency Regulations 2006; and finally, the inherent jurisdiction of common law courts. This provides a stark contrast with jurisdictions such as Hong Kong, ${ }^{50}$ which rely almost exclusively on the common law power in resolving CBI matters.

Despite the intervention of statute, the power continues to be highly relevant in the context of globalised markets, particularly in those common law jurisdictions where the statutory framework for cross-border insolvency is underdeveloped. As noted by Kawaley $\mathrm{J}$ of the Supreme Court of Bermuda, writing extracurially:

'Unless and until legislation based on the UNCITRAL Model Law on Cross-Border Insolvency is implemented in Bermuda and elsewhere in the British offshore world, the common law on judicial co-operation will continue to thrive. This is not simply because commercial necessity will compel recourse to the common law in the absence

\footnotetext{
${ }^{46}$ Gabriel Moss, 'International Jurisdiction of Courts in the USA and England' in Anthon Verweij and Bob Wessels, 'Comparative and International Insolvency Law Central Themes and Thoughts' (INSOL Europe Technical Series, 2009) 3, available at: 〈http://www.iiiglobal.org/sites/default/files/GabrielMoss.pdf> .

47 This is discussed further in Part III below. For a more detailed treatment of the history of ancillary proceedings, see Paul Omar, 'Developments in Cross-Border Insolvency Practice in the United Kingdom' (2002) 14(2) Bond Law Review 347.

${ }^{48}$ Singularis Holdings Limited (Appellant) v PricewaterhouseCoopers (Respondent) [2014] UKPC 36 [11] (per Lord Sumption). See further in Part IVD below.

${ }^{49}$ Council Regulation (EC) 1346/2000 on Insolvency Proceedings. This has now been amended by Regulation (EU) 848/2015 of the European Parliament and of the Council of 20 May 2015 on insolvency proceedings (recast), which entered into force on 26 June 2015 and will apply to insolvency proceedings from 26 June 2017. The European Insolvency Regulation will apply until the UK formally withdraws from the EU. What, if anything, will take its place is a matter of speculation.

${ }^{50}$ In Joint Official Liquidators of A Co v B [2014] 4 HKLRD 374 [11], Harris J noted that: 'Hong Kong's insolvency legislation contains no provisions dealing with cross-border insolvency. However, at common law the court has power to recognise and grant assistance to foreign insolvency proceedings.'
} 
of statutory provisions. In addition, this is attributable to the commercial contextual reality that the offshore world is quintessentially global in character. ${ }^{, 51}$

Given that the power continues to survive in many common law jurisdictions, the importance of the power should not be discounted. The analysis below identifies the factors that have shaped and moulded the applications of the power.

\section{What influences the scope of the power?}

Prior to considering the factors that have influenced the exercise of the inherent power, it is worth noting the comments of Ian Fletcher, as cited in the Hong Kong case of Joint Official Liquidators of A Co $v B:^{.52}$

'[C]ertain factors appear to militate against the English courts' powers of assistance being more frequently invoked, even against a background of steady growth in the numbers of insolvencies with cross-border aspects. One reason is the relatively underpublicised state of the law, much of which is contained in reports of cases originally decided many years ago. Unfamiliarity with these Common Law precedents and with their significance from the standpoint of obtaining active assistance from the English courts is likely to be one reason for their underutilisation... ${ }^{53}$

This general lack of familiarity with the 'state of the law' has arguably been redressed since Cambridge Gas, following the proliferation of case law seeking to invoke the power. Much of the following analysis considers the case law as it has developed in the years following Lord Hoffmann's dicta in Cambridge Gas.

\section{A Whether the jurisdiction recognises 'modified universalism'}

As alluded to earlier, the notion that cross-border insolvency proceedings are 'universal' in nature has been influential in the discourse concerning the inherent power. This is because it often "carries with it a further principle: that the courts will actively assist the foreign insolvency proceeding. ${ }^{54}$ But what is actually meant by the term 'universalism'?

The doctrine of 'universalism' - or 'modified universalism' as it has come to be regarded in its more limited form - is the principle that insolvency proceedings should be dealt with under a single, unified system, with appropriate safeguards to avoid manifestly unfair

\footnotetext{
${ }^{51}$ Ian Kawaley, 'Judicial co-operation in cross-border insolvency cases: recent offshore developments' (2007) 20(8) Insolvency Intelligence 113, 121-2. For similar sentiments, see the recent Singapore case of Re OptiMedix Ltd (in liquidation) and another matter [2016] SGHC 108, [17] and [26].

52 [2014] HKEC 1244.

${ }^{53}$ Ian Fletcher, Insolvency in Private International Law (2nd edition, OUP, 2007) para 4.02.

${ }^{54}$ Tom Smith QC, 'Recognition of Foreign Corporate Insolvency Proceedings at Common Law' in Richard Sheldon QC (ed), Cross-Border Insolvency (4th edition, Bloomsbury Professional, 2015) 6.11.
} 
outcomes. 'Modified universalism' is widely recognised, and is 'strongly embodied' in the UNCITRAL Model Law on Insolvency. ${ }^{55}$ The scope of the principle itself is 'controversial and has been the subject of judicial disagreement at the highest level. ${ }^{, 56}$

While universalism encourages jurisdictions to treat insolvency proceedings as 'unified' across jurisdictions, the dominant approach in many jurisdictions is that of territoriality. As the name suggests, courts in territorialist jurisdictions will usually disregard the impact of foreign proceedings in resolving the local affairs of an insolvent company. Territorialist tendencies can in large part explain the reluctance of countries in the Asian region to adopt the Model Law, ${ }^{57}$ which is potentially viewed as undermining national sovereignty through the 'erosion of a jurisdiction's ability to direct and administer its own affairs. ${ }^{58}$

Speaking with respect to the difficulties of universalism, McCormack notes:

'The advantages of universalism can be realized fully only if all states practise it. If one State has universalist pretensions whereas another state practises territorialism then jurisdictional conflicts will arise and the national interests of the universalist state may be compromised. The universalist state yields up local assets for the benefit of foreign creditors, including creditors in a territorialist state, whereas the territorialist state does not reciprocate for the benefit of creditors in the universalist state. $\cdots$

But territorialism has its unattractive features. National chauvinism is especially unappealing if it overtly discriminates against foreign creditors. ${ }^{59}$

A number of jurisdictions, including many of those surveyed in this article, have expressly endorsed 'modified universalism'. For example, the US case of Maxwell Communication Corporation noted that 'the United States in ancillary bankruptcy cases has embraced an approach to international insolvency which is a modified form of universalism accepting the central premise of universalism... that assets should be collected and distributed on a worldwide basis, but reserving... [judicial] discretion. ${ }^{60}$

\footnotetext{
55 Reid Mortensen, Richard Garnett and Mary Keyes, 'Private International Law in Australia' (3rd edition LexisNexis Butterworths, 2015) 533 citing Akers v Deputy Commissioner of Taxation (2014) 311 ALR 167; [2014] FCAFC 57 at [28]; Re HIH Insurance Ltd [2008] 1 WLR 852 at 856-7.

${ }^{56}$ Tom Smith QC, 'Recognition of Foreign Corporate Insolvency Proceedings at Common Law' in Richard Sheldon QC (ed), Cross-Border Insolvency (4th edition, Bloomsbury Professional, 2015) 6.44.

${ }^{57}$ Chief Justice Spigelman AC, 'Cross-Border Insolvency: Co-operation or Conflict? (Address at the INSOL International Annual Regional Conference, Shanghai, 16 September 2008) 31.

58 Asian Development Bank, 'Technical Assistance Completion Report' (TA 5975 - REG: Promoting Regional Cooperation in the Development of Insolvency Law Reforms' (2009), available at: <http://www.adb.org/sites/default/files/project-document/64987/34496-reg-tcr.pdf>; see also S. Chandra Mohan, 'Cross-border Insolvency Problems: Is the UNCITRAL Model Law the Answer?' (2012) 21(3) International Insolvency Review 199, 218-219.

${ }^{59}$ Gerard McCormack, 'Universalism in Insolvency Proceedings and the Common Law' (2012) 32(2) Oxford Journal of Legal Studies 325, 328.

${ }^{60}$ In re Maxwell Communication Corporation (1994) 170 BR 800.
} 
The primacy of modified universalism in England was famously proclaimed by Lord Hoffmann in $H I H^{61}$ in his oft-quoted passage:

'The primary rule of private international law... applicable to this case is the principle of (modified) universalism, which has been the golden thread running through English cross-border insolvency law since the eighteenth century. That principle requires that English courts should, so far as is consistent with justice and UK public policy, cooperate with the courts in the country of the principal liquidation to ensure that all the company's assets are distributed to its creditors under a single system of distribution. ${ }^{, 62}$

Lord Hoffmann qualified this 'rule' by explaining that it is 'very much a principle rather than a rule. It is heavily qualified by exceptions on pragmatic grounds... [I]t is an aspiration. ${ }^{63} \mathrm{In}$ Rubin, Lord Collins quipped that universalism is 'a trend, but only a trend. ${ }^{64}$ Even Lord Sumption in Singularis, who wished to confine many aspects of the inherent power, did not question the principle of modified universalism. ${ }^{65}$ Tom Smith QC notes that 'on examination, it can be seen that the foundations of the aspiration of universality in English law are deeply rooted. ${ }^{66}$ The real question now relates to how lustrous this 'golden thread' continues to be. Recognising the principle or 'trend' of modified universalism requires a degree of cooperation from common law courts, which often calls for an exercise of the court's inherent power.

Singapore provides a unique example of a common law jurisdiction that to date has not wholly embraced modified universalism. ${ }^{67}$ Its earlier Insolvency Law Review Committee noted the paucity of case law in this area. ${ }^{68}$ It further commented that 'there [had] also been some suggestion that certain previous decisions of the Singapore courts preclude such recognition at common law. ${ }^{69}$ Arguably, recognition of modified universalism has been complicated by Singapore's statutory 'ring-fencing' provisions, ${ }^{70}$ which require courts to

\footnotetext{
${ }^{61}$ Re HIH Casual and General Insurance Ltd [2008] 1 WLR 852.

${ }^{62}$ Ibid [30].

${ }^{63}$ Ibid [7].

${ }^{64}$ Rubin v Eurofinance SA [2013] 1 AC 236 [16].

${ }^{65}$ Singularis Holdings Limited (Appellant) v PricewaterhouseCoopers (Respondent) [2014] UKPC 36 [17].

${ }^{66}$ Tom Smith QC, 'Recognition of Foreign Corporate Insolvency Proceedings at Common Law' in Richard Sheldon QC (ed), Cross-Border Insolvency (4th edition, Bloomsbury Professional, 2015) 6.7.

${ }^{67}$ As mentioned before (n 4), Singapore is on course to adopt the Model Law, which will significantly reshape how it handles cross-border insolvency matters.

68 Insolvency Law Review Committee, 'Final Report' (2013) 230, available at: $<$ https://www.mlaw.gov.sg/content/dam/minlaw/corp/News/Revised\%20Report\%20of\%20the\%20Insolvency\% 20Law\%20Review\%20Committee.pdf $>$.

${ }^{69}$ Ibid 230.

${ }^{70}$ See Companies Act (Chapter 50) Singapore, s 377(3)(c).
} 
prioritise debts incurred in Singapore above all others - irrespective of whether the Singaporean proceedings could be regarded as 'ancillary' ${ }^{71}$

Notwithstanding the comments of the Insolvency Law Review Committee regarding the application of modified universalism, it is clear that the Singaporean Courts are alive to developments overseas concerning the 'common law ancillary liquidation doctrine... adopted in the House of Lords' decision in In Re HIH Casualty'. ${ }^{72}$ In the recent case of Beluga Chartering, the court noted that:

'There is... ample authority for the proposition that the common law ancillary liquidation doctrine continues to exist alongside the statutory insolvency regime where no other statutory provision has been made. ${ }^{73}$

Thus, the extent to which modified universalism is entrenched in a jurisdiction and recognised by the judiciary is likely to affect the scope of assistance a court is willing to provide, especially where there is no statutory framework preventing the court from cooperating.

This approach was confirmed in the recent Singapore case of Re Opti-Medix Ltd (in liquidation) and another matter [2016] SGHC 108, which involved applications for the recognition of foreign insolvency proceedings in Japan in respect of companies incorporated in the British Virgin Islands. Noting that there had been no Singapore decision on the recognition of foreign liquidators from jurisdictions other than the place of incorporation, the court held that recognition of the foreign proceedings was justified on the basis that Japan 'was where the bulk of the business and transactions of the Companies [had] occurred'. Citing the remarks of Lord Collins in Rubin that courts should not recognise the centre of main interest (COMI) and the country with which the judgment debtor had a sufficient or substantial connection as the competent jurisdiction as this had 'all the hallmarks of legislation', the court stated that 'the development of the common law should not be so constrained. ${ }^{, 74}$ In addition to the COMI test, the court stated that the recognition of the foreign proceedings could also be justified on practical grounds:

${ }^{71}$ See Chief Justice Spigelman AC, 'Cross-Border Insolvency: Co-operation or Conflict? (Address at the INSOL International Annual Regional Conference, Shanghai, 16 September 2008) 31. See also Tohru Motobayashi v Official Receiver [2000] 4 SLR 529 and the recent case of Re Opti-Medix Ltd (in liquidation) and another matter [2016] SGHC 108, where the court allowed the remittal of assets on condition that the preferential debts and debts incurred in Singapore would be paid before remitting the surplus out of Singapore: [7] and [13].

${ }^{72}$ Beluga Chartering GmbH (in liquidation) and others v Beluga Projects (Singapore) Pte Ltd (in liquidation) and another (deugro (Singapore) Pte Ltd, non-party) [2014] SGCA 14.

${ }^{73}$ Ibid, emphasis added. See also the comments of Wong Li Fern, who notes 'Singapore laws embrace the doctrine of comity through the acceptance of common law': Wong Li Fern, 'To Better the Insolvency Regime: A question of assimilating the Model Law' (2003) 23 Sing LR 211.

${ }^{74}$ Re Opti-Medix Ltd (in liquidation) and another matter [2016] SGHC 108 [20]-[21], where Aedit Abdullah JC cited the remarks of Lord Collins in Rubin v Eurofinance SA [2013] 1 AC 236 at [129] and also the comments of 
'Where the interests of the forum are not adversely affected by a foreign order, the courts should lean towards recognition. This approach could be justified on the bases of not only comity but also of business practicality. ${ }^{75}$

Significantly, the court noted that ' $[\mathrm{t}] \mathrm{he}$ tone of the approach in Beluga and the telegraphed adoption of the UNCITRAL Model Law on Cross-Border Insolvency... [were] indicators that Singapore [was] warming to Universalist notions in its insolvency regime. ${ }^{, 76}$

\section{B Whether the domestic statutory regime can be 'disapplied'}

One of the most important factors that shapes the scope of the inherent power to provide assistance concerns the judiciary's interpretation of local legislation and its impact. Is the presence of local legislation proof that the legislature intended all insolvency proceedings to proceed strictly according to the statute, even in cases where the legislation is silent on the matter before the court? Or is the inherent power able to prevail over a local statutory regime to ensure there is one, universal proceeding?

This Part considers the circumstances in which the local legislation is designed to 'cover the field', the debate surrounding whether a court may 'disapply' domestic legislation in providing assistance to foreign insolvency proceedings, and finally, how the absence of a statutory framework might impact the exercise of the power.

\section{Does the legislation cover the field?}

The inherent power appears limited, or even redundant, where domestic legislation 'covers the field' in CBI matters. At the time of introducing the Model Law, the United States House of Representatives noted that 'Chapter 15 is intended to be the exclusive door to ancillary assistance to foreign proceedings. The goal is to concentrate control of these questions in one court. $^{77}$

This 'exclusive door' was tested in the US Bear Stearns case ${ }^{78}$ where the court noted that:

'Prior to the enactment of Chapter 15, access to the United States courts by a foreign representative was not dependent on recognition; rather, all relief under section 304

Tom Smith QC, 'Recognition of Foreign Corporate Insolvency Proceedings at Common Law' in Richard Sheldon QC (ed), Cross-Border Insolvency (4th edition, Bloomsbury Professional, 2015) 6.8.

${ }^{75}$ Ibid [26].

${ }^{76}$ Ibid [17].

${ }^{77}$ US House of Representatives, 'Bankruptcy Abuse Prevention and Consumer Protection Act of 2005: Report of the Committee on the Judiciary House of Representatives to accompany s 256 together with dissenting, additional dissenting and additional minority views' (109th Congress 1st Session, Report 109-31 Part 1, Union Calendar No 14, 8 April 2005) 110.

${ }^{78}$ Re Bear Stearns High-Grade Structured Credit Strategies Master Fund Ltd, 389 B.R. 325 (2007) 332. 
was discretionary and based on subjective, comity-influenced factors... By establishing a simple, objective eligibility requirement for recognition, Chapter 15 promotes predictability and reliability. The considerations for post-recognition relief remain flexible and pragmatic in order to foster comity and cooperation in appropriate cases. $^{79}$

Thus the above case confirms that the Chapter 15 legislation is intended to operate as an exhaustive procedure on ancillary CBI matters. Yet the Model Law, as reflected in Article 7 was intended by its draftees to be an additional gateway to those provided under local laws: $:^{80}$

'Nothing in this Law limits the power of a court or a [insert the title of the person or body administering a reorganization or liquidation under the law of the enacting State] to provide additional assistance to a foreign representative under other laws of this State. ${ }^{, 81}$

This Article was not replicated in Chapter $15 .{ }^{82}$ A similar approach, albeit within narrower parameters, was adopted by the Supreme Court of The Bahamas in the recent case of In the Matter of Caledonian Bank Limited (In Official Liquidation under Supervision of The Grand Court of The Cayman Islands), ${ }^{83}$ where the court heard an application to recognise liquidators of The Cayman Islands as foreign representatives. The court held that neither the Cayman proceedings nor the Cayman liquidators came within the statutory definition of 'foreign proceedings' or 'foreign representatives' under the Bahamian statute ${ }^{84}$ and that the 'open gate' for recognition of foreign representatives under the common law power had not survived the relevant statute. ${ }^{85}$ The court noted, however, that it was not the common law principle itself that was 'repealed' or 'abolished', but 'merely its application to persons outside the statutory class of foreign representatives. ${ }^{86}$

The position in the US can be contrasted with jurisdictions such as Australia and the UK where there appears to have been a deliberate choice to leave open numerous gateways to resolve CBIs. ${ }^{87}$ Indeed, Australian case law has suggested that parties are completely unbridled in choosing the gateway they would prefer.

${ }^{79}$ Ibid 333.

80 UNCITRAL, 'UNCITRAL Model Law on Cross-Border Insolvency with Guide to Enactment and Interpretation' (2014) 5.

81 Ibid.

${ }^{82}$ See the wording of Chapter 1 ' $\$ 1507$ - Additional assistance'.

${ }^{83}$ 2015/COM/com/00034.

${ }^{84}$ Companies Winding-up Amendment Act 2011, s 253.

85 The court stated at [52] that recognising foreign representatives outside the statutory definition would 'be tantamount to ignoring the legislative intention of Parliament when it passed the Bahamian Act.'

${ }^{86}$ In the Matter of Caledonian Bank Limited (In Official Liquidation under Supervision of The Grand Court of The Cayman Islands) 2015/COM/com/00034 at [51].

${ }^{87}$ See, for example, McGrath \& Anor as Liquidators of HIH Insurance Ltd [2008] NSWSC 881 [17]. 
For example, in the McGrath case, Barrett $\mathrm{J}$ discussed the relationship between section 581 of the Corporations Act and the UNCITRAL Model Law as it had been adopted in Australia. Justice Barrett expressed the view that parties are free to choose whichever gateway they would prefer, noting that Parliament had made 'a deliberate decision in each country that the older system of cross-border assistance should be retained despite the enactment of the Model Law legislation. ${ }^{, 88}$

Thus, in contrast to the position in the US, Australia and the UK have not created a sole gateway for the provision of ancillary assistance in CBIs. The inherent power continues to remain an open gateway for courts to provide assistance.

\section{$2 \quad$ Is the court able to 'disapply' domestic legislation?}

Lord Hoffmann in $H I H^{89}$ ignited what is arguably the most heated debate surrounding the inherent power - where there is no legislation designed to 'cover the field', but there is an applicable domestic statutory scheme, to what extent will courts be able to ignore or 'disapply' that scheme? The scope of the power to assist may be limited depending on whether a court can 'disapply' - or avoid applying - the local insolvency regime. This was considered in $\mathrm{HIH}$ by both Lord Scott and Lord Hoffmann.

$H I H$ involved four Australian insurance companies that were being wound up in New South Wales. Provisional liquidators had been appointed in England. The key question under consideration was whether the English Court was able to remit assets collected in England to New South Wales pursuant to a letter of request issued by the New South Wales Court. There were important differences in the priority regime between England and Australia that would significantly alter the position of some English creditors.

The House of Lords was divided on the question of whether, in deciding to remit the assets to Australia, the statutory regime established under section 426 of the Insolvency Act 1986 could be disregarded. ${ }^{90}$ Lord Hoffmann was of the view that it could:

\footnotetext{
${ }^{88}$ Ibid [17].

${ }^{89}$ [2008] 1 WLR 852.

${ }^{90}$ Section 426 of the Insolvency Act 1986 relevantly provides:
}

'...(4) The courts having jurisdiction in relation to insolvency law in any part of the United Kingdom shall assist the courts having the corresponding jurisdiction in any other part of the United Kingdom or any relevant country or territory.

(5) For the purposes of subsection (4) a request made to a court in any part of the United Kingdom by a court in any other part of the United Kingdom or in a relevant country or territory is authority for the court to which the request is made to apply, in relation to any matters specified in the request, the insolvency law which is applicable by either court in relation to comparable matters falling within its jurisdiction. In exercising its discretion under this subsection, a court shall have regard in particular to the rules of private international law...'

Jurisdictions that are 'relevant countries' are found in the Co-operation of Insolvency Courts (Designation of Relevant Countries and Territories) Order 1986. Of importance in HIH was the fact that Australia was a 'relevant country'. 
'The whole doctrine of ancillary winding up is based upon the premise that in such cases the English court may "disapply" parts of the statutory scheme by authorising the English liquidator to allow actions which he is obliged by statute to perform according to English law to be performed instead by the foreign liquidator according to the foreign law (including its rules of the conflict of laws). ${ }^{91}$

Lord Scott forcefully disagreed:

'The English courts have a statutory obligation in an English winding up to apply the English statutory scheme and have, in my opinion, in respectful disagreement with my noble and learned friend Lord Hoffmann, no inherent jurisdiction to deprive creditors proving in an English liquidation of their statutory rights under that scheme. ${ }^{, 92}$

Accordingly, in Lord Scott's view, the assets could only be remitted under section 426 of the Insolvency Act as that was part of the applicable statutory scheme. This mirrored Lord Scott's earlier views in In re Bank of Credit and Commerce International SA (No 10): ${ }^{93}$

'The courts have, in my judgment, no more inherent power to disapply the statutory insolvency scheme than to disapply the provisions of any other statute. ${ }^{94}$

Prior to Cambridge Gas, in the case of $A l S_{a b a h}{ }^{95}$ the Privy Council took a similarly restrictive view on the application of the inherent power in circumstances where there was applicable domestic legislation. Lord Collins in Singularis confirmed that, to the extent Cambridge Gas and Al Sabah were inconsistent, Al Sabah was correct:

'In my judgment Lord Walker's dictum in the opinion in Al Sabah v Grupo Torres (in which, among others, Lords Hoffmann and Scott concurred) was plainly right... to the extent it is inconsistent with the passage in Cambridge Gas. ${ }^{96}$

Lord Scott's narrow formulation of the inherent power's application, with whom Lord Neuberger agreed, has itself been subject to criticism:

'This strand of thought was based on a fundamental misconception... The two Lords who followed this approach both seemed to think that the English statute of the Insolvency Act 1986 was some kind of code of insolvency law. They believed that if you needed to find insolvency law you would find it in the statute. Of course anybody in the field would agree that this is wrong. Throughout the entire English insolvency

\footnotetext{
${ }^{91}$ [2008] 1 WLR 852 [19].

92 Ibid [59].

${ }^{93}$ [1997] Ch 213.

${ }^{94}$ Ibid 239.

95 [2005] 2 AC 333 [104].

${ }^{96}$ Singularis Holdings Limited (Appellant) v Pricewaterhouse Coopers (Respondent) [2014] UKPC 36 [107].
} 
law, there have always been parallel judge-made rules that have made important provisions next to and separate from the statutory provisions. ${ }^{97}$

The recent Singaporean case of Beluga considered the ability of Singaporean courts to disapply the 'statutory insolvency scheme'. Without having to decide the matter, the court hinted that 'remittal of assets to a foreign liquidator would be permitted even if the distribution in the foreign liquidation differs from that mandated by Singapore's statutory insolvency scheme, as long as it is not contrary to the principles of justice or local public policy. ${ }^{, 98}$

While the impasse in $H I H$ is unlikely to be resolved without determining whether the legislation should cover the field, it is clear that views surrounding the application of local legislation are highly relevant in determining the scope of the inherent power. ${ }^{99}$ Where a court regards itself as being compelled to apply the local regime, irrespective of the global nature of the proceedings, the utility of the inherent power is significantly diminished.

3 Is there an absence of domestic legislation addressing cross-border insolvency matters?

As noted below, it has been suggested by a judge in Hong Kong that the absence of legislation addressing CBI matters leads to the inference that courts should take a restrictive view toward judicial assistance. Calls for reform to Hong Kong's CBI regime were made as early as 1996 by Charles Booth who recognised the need for CBI reform. ${ }^{100}$ Despite being mentioned in numerous government reports, ${ }^{101}$ no serious reforms appear to be on the horizon despite a root and branch review of Hong Kong's insolvency regime in 2013. ${ }^{102}$

The case of Joint Official Liquidators of A Co $v B$ concerned a letter of request addressed to the Hong Kong courts from a Cayman Islands court seeking, inter alia, recognition of the

\footnotetext{
${ }^{97}$ Gabriel Moss, 'International Jurisdiction of Courts in the USA and England' in Anthon Verweij and Bob Wessels, 'Comparative and International Insolvency Law Central Themes and Thoughts' (INSOL Europe Technical Series, 2009) 10, available at: 〈http://www.iiiglobal.org/sites/default/files/GabrielMoss.pdf〉.

${ }^{98}$ Beluga Chartering GmbH (in liquidation) and others v Beluga Projects (Singapore) Pte Ltd (in liquidation) and another (deugro (Singapore) Pte Ltd, non-party) [2014] SGCA 14 [77].

${ }^{99}$ [2008] 1 WLR 852 [19].

${ }^{100}$ Charles Booth, 'Living in Uncertain Times: The Need to Strengthen Hong Kong Transnational Insolvency Regime' (1996) 34 Columbia Journal of Transnational Law 389.

101 See Legislative Council Panel on Financial Affairs, 'Modernization of Corporate Insolvency Law' (2011) CB(1)11-12(05), 5, available at: <http://www.legco.gov.hk/yr11-12/english/panels/fa/papers/fa1107cb1-237-5e.pdf>; Tanner DeWitt Solicitors, 'Challenges of Cross-Border Insolvencies' (Talk presented to the 16th Commonwealth Law Conference in Hong Kong), available at: <http://www.tannerdewitt.com/challenges-ofcross-border-insolvencies/>.

102 Financial Services and the Treasury Bureau, 'Improvement of Corporate Insolvency Law Legislative Proposals' (Consultation document, April 2013), available at: <http://www.fstb.gov.hk/fsb/ppr/consult/doc/impcill_consult_e.pdf>; Latham, and Watkins, 'Hong Kong Jurisdiction Relating to Cross Border Insolvency Issues Becomes Increasingly Clear' (Client Alert, 22 April 2013).
} 
Caymanian liquidators and for the respondents to produce certain documents. While acknowledging the 'expansive view of the extent to which established common law principles require the court to recognise foreign liquidators', ${ }^{103}$ Harris $\mathrm{J}$ also raised concern about Hong Kong's inadequate statutory framework for addressing CBIs.

'It would... invite the argument that the failure to make such an obvious amendment indicated that Hong Kong's courts should take a more restrictive view of the extent to which they should assist foreign liquidators from other common law jurisdictions. ${ }^{104}$

The recent case of Joint Provisional Liquidators of BJB Career Education Company Limited (in provisional liquidation) $v$ Xu Zhendong [2016] HKCFI 1930 also involved a letter of request from a Cayman Islands Court for orders allowing the provisional liquidators to examine the former chairman and director of a company and requiring him to attend an oral examination, respond to written interrogatories, transfer or deliver up documents and property belonging to the company and provide other information relating to the company as requested by the provisional liquidators. Harris $\mathrm{J}$ noted the development of a standard order in Hong Kong since Joint Official Liquidators of A Company that expressly empowered the foreign liquidators without further order of the court to take possession and control of the company's property and investigate its affairs and to bring proceedings to facilitate these processes, and which provided for an automatic stay of the commencement or continuation of proceedings against the company or its assets in Hong Kong without the leave of the court. ${ }^{105}$

What had remained undecided, Harris $\mathbf{J}$ noted, was whether an order could be made for the oral examination of an officer of a foreign company or other persons that would in the domestic context be made pursuant to section 221 of the Companies (Winding Up and Miscellaneous Provisions) Ordinance. ${ }^{106}$ Citing Singularis, Harris J held that such an order could be made on the basis that 'the common law power of assistance extends to ordering an oral examination if such a power (a) exists in the jurisdiction of liquidation and that is the jurisdiction of the place of incorporation and (b) the power exists in the assisting jurisdiction; as is the case in Hong Kong., 107

\footnotetext{
103 Joint Official Liquidators of A Co v B [2014] 4 HKLRD 374 [17].

${ }^{104}$ Ibid [11].

105 Joint Provisional Liquidators of BJB Career Education Company Limited (in provisional liquidation) $v$ Xu Zhendong [2016] HKCFI 1930 [3].

106 Ibid [4].

${ }^{107}$ Ibid [7]. Harris J at [8]-[15] rejected an argument that the granting of an order of recognition and assistance in response to a letter of request was caught by Article 96 of the Basic Law of the Hong Kong Special Administrative Region of the People's Republic of China, which provides that '[w]ith the assistance or authorization of the Central People's Government, the Government of the Hong Kong Special Administrative Region may make appropriate arrangements with foreign states for reciprocal juridical assistance.' Citing Rubin $v$ Eurofinance, Singularis and other cases concerning the principles of modified universalism, Harris $\mathbf{J}$ held that his order would not infringe Article 96 on the basis that 'reciprocity is not a necessary component of recognition and assistance and that it is erroneous to view an order recognising the appointment of a liquidator appointed in the place of a company's incorporation and an order providing assistance to allow him to carry out his function
} 
The experience in Hong Kong, as reflected in the above comments of Harris $\mathrm{J}$ in Joint Official Liquidators of $A \operatorname{Co} v B$, indicates that the absence of relevant legislation may influence the willingness of courts to expand the scope of the inherent power and may militate against an expansive view.

\section{Whether there is a need for similarity or equivalence between a foreign insolvency regime and the local regime}

The willingness of courts to provide assistance may be shaped by the similarity of the jurisdiction from which they have received a request for assistance. A particularly influential factor is the extent to which the foreign jurisdiction is prepared to recognise a pari passu distribution. In the Hong Kong case of CCIC Finance Ltd $v$ Guangdong International Trust, ${ }^{108}$ a liquidation had commenced in Mainland China and an application had been made in Hong Kong for a stay of all proceedings. Deputy Judge Gill also had to consider whether a garnishee order against CCIC should be granted.

One of the most important considerations in CCIC was that the "paramount principle of pari passu... distribution [was] strictly being adhered to.' ${ }^{109}$ To have granted the garnishee order "would have offended the principle of a pari passu distribution [and] it follows that all enforcement action should properly not be allowed to proceed. ${ }^{110}$ The relevant principle was:

'[W]here a foreign jurisdiction is actively and openly pursuing a liquidation in which it says it intends to treat all creditors, domestic and foreign, alike, and then patently does so, it is not, I believe, for the courts of Hong Kong to interfere with that process.' 111

Despite the disagreement between the members of the House of Lords in $H I H$, it was not in dispute that an English court had the power to remit assets where the foreign jurisdiction would distribute the assets on a pari passu basis. This point was recognised by Richards $\mathrm{J}$ in in Re Swissair: ${ }^{112}$

'The issue in $[H I H]$ was whether the English court should order the remittal of assets by the provisional liquidators in ancillary English proceedings to the liquidators in the principal Australian liquidation, in circumstances where there would not in Australia

\footnotetext{
as an arrangement for reciprocal juridical assistance.' Harris $\mathbf{J}$ further stated at [14] that the power to provide judicial assistance was 'founded firmly in the common law'.

108 [2005] HKEC 1180.

109 CCIC Finance Ltd v Guangdong International Trust \& Investment Corp \& Guangdong International Trust and Investment Corp Hong Kong (Holdings) Ltd (Garnishee) [2005] HKEC 1180 [84].

${ }^{110}$ Ibid [102].

${ }^{111}$ Ibid [101].

${ }^{112}$ Re Swissair Schweizerische Luftverkehr-Aktiengesellschaft [2009] EWHC 2099 (Ch).
} 
be a pari passu distribution among unsecured creditors to the material disadvantage of some creditors. The controversial issue was not whether the court had jurisdiction under its general powers to order remittal where there would be a pari passu distribution in the foreign liquidation, but whether it had such jurisdiction in a case where there would not be.'113

Richards $\mathbf{J}$ went on to note the view of Lord Neuberger that the power to remit assets where the distribution would not be in accordance with the English insolvency regime derived only from section 426 and not from the inherent common law power. On this basis, it is uncertain whether the courts in the UK would exercise the inherent power in circumstances where the foreign insolvency regime diverges from the local regime in a material sense.

Equivalence in terms of the type of order being sought is also a significant factor. In the Hong Kong case of Joint Administrators of African Minerals Ltd v Madison Pacific Trust, Harris $\mathbf{J}$ considered that:

'[A]lthough in my opinion the Hong Kong Court can take a generous view of its power to assist a foreign liquidation process this is limited by the extent to which the type of order sought is available to a liquidator in Hong Kong under our insolvency regime and common law and equitable principles. ${ }^{, 114}$

The order sought - 'restraining the sale of... charged shares to aid the administration in England' - had no statutory, common law or equitable power equivalent in Hong Kong. Harris $\mathbf{J}$ described this as 'an impermissible extension of the common law principle that requires the court to recognise foreign liquidators and assist them. ${ }^{115} \mathrm{He}$ refused to recognise the foreign liquidator on this basis.

This was similarly considered in the recent Hong Kong case of G Ltd:

'In the case of liquidators appointed in jurisdictions with similar insolvency regimes to Hong Kong assistance may extend to granting orders that give foreign liquidators substantially similar powers to, for example, investigate the affairs of a company by examination and orders for the production of documents as a domestic liquidator would have. Recently the Privy Council has in Singularis Holdings Ltd $v$ PricewaterhouseCoopers confirmed this and explained comprehensively the applicable common law principles and the limitations on the power to extend assistance to foreign liquidators. ${ }^{116}$

\footnotetext{
${ }^{113}$ Ibid [6-8]. Emphasis added.

${ }^{114}$ Joint Administrators of African Minerals Ltd v Madison Pacific Trust [2015] HKEC 641.

${ }^{115}$ Ibid.

${ }^{116}$ G Ltd [2015] HKEC 2298 [5].
} 
Similarity in insolvency regimes also appears to be a relevant consideration for Australian courts in deciding whether to issue a letter of request to a foreign court. One of the three relevant conditions in deciding to issue a letter of request is that 'there is utility in the request in the sense that the foreign court is likely to accept and act upon the request if it is made.'117 Ascertaining whether a foreign court is likely to act upon the request is likely to involve some determination of the similarity of the foreign court's insolvency regime. For this purpose, a court looking to satisfy itself of the utility of a request will often place considerable weight on the evidence of expert witnesses in the form of foreign legal opinions. ${ }^{118}$ Thus, similarity and equivalence may be relevant factors for courts in determining whether to request or provide assistance.

\section{IV $=$ Circumstances where the power has been exercised}

This Part highlights the principal circumstances in which courts have exercised the inherent power. It is not intended to be exhaustive, but instead provides a cross-section of the cases that have invoked the power.

\section{A Ordering a stay of proceedings where there is 'pending a process of universal distribution'}

One of the key methods through which a court may provide assistance to a foreign liquidator or court is by ordering a stay of the local (ancillary) proceedings while the process of universal distribution' is being carried out in the other (main) proceeding. ${ }^{119}$ This has been described as 'perhaps the most important example... of the extent of judicial assistance to foreign insolvency proceedings, since they involve declining to give effect to rights recognised as a matter of domestic law. ${ }^{120}$

A stay of proceedings is an 'order made by a court suspending all or part of an action either before or after a determination by a court in respect of the action', and may be 'temporary or permanent. ${ }^{121}$ Exercising a stay to provide assistance to a foreign court is a good example of a court embracing universalist ideals.

An early example of a court exercising a stay of local proceedings to provide assistance can be found in the African Farms decision, where the execution of a local judgment creditor's

\footnotetext{
117 [2008] NSWSC 780.

118 See Yeo and Rambaldi (as liquidators), in the matter of Rennie Produce (Aust) Pty Ltd (in liquidation) [2015] FCA 849 [15]. See also Re HIH Insurance Limited (In Liquidation) \& Ors [2004] NSWSC 454 [14] where Barrett J placed reliance on the opinion of Linklaters vis-à-vis the likelihood of English courts acting on an Australian request for assistance.

${ }^{119}$ Galbraith v Grimshaw [1910] AC 508 (per Lord Dunedin).

${ }^{120}$ Tom Smith QC, 'Recognition of Foreign Corporate Insolvency Proceedings at Common Law' in Richard Sheldon QC (ed), Cross-Border Insolvency (4th edition, Bloomsbury Professional, 2015) 6.13.

${ }^{121}$ Lexis Nexis, Encyclopaedic Australian Legal Dictionary (2011) 'Stay'.
} 
judgment was stayed as a means of assisting the English liquidator in administering the assets. ${ }^{122}$ The notion that courts could assist by refusing to act in insolvency proceedings was considered by Lord Dunedin in Galbraith v Grimshaw:

'[So] far as the general principle is concerned it is quite consistent with the comity of nations that it should be a rule of international law that if the Court finds that there is already pending a process of universal distribution of a bankrupt's effects it should not allow steps to be taken in its territory which would interfere with the process of universal distribution..., 123

This notion was recognised in the Hong Kong case of CCIC Finance Ltd $v$ Guangdong International Trust. ${ }^{124}$ As stated by Deputy Judge Gill:

'I propose to exercise my discretion by refusing the application for garnishee order absolute. My primary reason for doing so is because... the... liquidation is being pursued on the basis of a universal collection and distribution of assets and the creditors world-wide are to be paid pari passu with each other subject only to ranking. To have granted the application would have offended the principle of equality in that one of the creditors, CCIC, would have achieved an unfair preference ahead of those others ranking at the same level.' 125

\section{B Remitting assets overseas to give effect to modified universalism}

Following Lord Hoffmann's approach in HIH outlined above, and in recognising the 'golden thread' of modified universalism, an English court may remit assets to another jurisdiction so long as it is 'consistent with justice and UK public policy'. This ensures that the company's assets are distributed to its creditors under a single system of distribution, and that the liquidation is administered according to the laws of the principal, as distinct from the ancillary, seat of liquidation. However, following Singularis, some doubt has been cast on the availability of asset remittal in circumstances where the foreign insolvency proceeding is conducted according to the law of a jurisdiction "whose substantive law of distribution is different'. ${ }^{126}$

In Singapore, despite its current legislation embodying clear territorialist tendencies, the recent case of Beluga Chartering $\mathrm{GmbH}^{127}$ considered the ability of Singapore courts to remit

\footnotetext{
122 Discussed above in Part II.

${ }^{123}$ Galbraith v Grimshaw [1910] AC 508 (per Lord Dunedin).

${ }^{124}$ CCIC Finance Ltd v Guangdong International Trust and Investment Corp \& Guangdong International Trust and Investment Corp Hong Kong (Holdings) Ltd (Garnishee) [2005] HKEC 1180.

${ }^{125}$ Ibid [101].

${ }^{126}$ Gerard McCormack and Anil Hargovan, 'Australia and the International Insolvency Paradigm' (2015) 37 Sydney Law Review 389, 402.

${ }^{127}$ Beluga Chartering GmbH (in liquidation) and others v Beluga Projects (Singapore) Pte Ltd (in liquidation) and another (deugro (Singapore) Pte Ltd, non-party) [2014] SGCA 14.
} 
assets in accordance with the 'ancillary liquidation doctrine'. The court was satisfied that 'the ancillary liquidation doctrine is historically entrenched as part of the common law' and that 'the... doctrine continues to exist... where no other statutory provision has been made.'128 The court also expressed the view that the foreign insolvency regime did not need to be identical for assets to be remitted.

\section{Granting a foreign administrator power as if they were a domestic administrator - or 'legislation by analogy'?}

In re Phoenix Kapitaldienst GmbH; Schmitt v Deichmann and Others, ${ }^{129}$ a German Ponzi scheme company was placed into administration. An order was granted by an English court granting the German administrator recognition at common law. It also granted the administrator equivalent powers a licensed insolvency practitioner would have had under the UK Insolvency Act 1986. The administrator applied for relief against the defendants to set aside transactions entered into at an undervalue. In the appeal against the recognition order, the exercise of the inherent power became relevant. As described by Proudman J, the inherent power was relevant because:

'the [European] Council [Insolvency] Regulation... [did] not apply because the company was an investment undertaking. [ $\mathrm{I}] \mathrm{t}$ is common ground that the UNCITRAL Model Law on Cross-Border Insolvency as reflected in the Cross-Border Insolvency Regulations $2006 .$. could not be invoked because of the date when it was incorporated into English law. As a result the administrator's only recourse in this court [was] to common law principles. ${ }^{, 130}$

Proudman J ultimately found that 'the court had the power at common law to recognise a foreign administrator and to provide him with the same assistance as it was entitled to provide in a domestic insolvency.' This included the power to set aside antecedent transactions (for example, preference payments), in circumstances where there was no prejudice to creditors. ${ }^{131}$

The re Phoenix decision received considerable criticism in later cases. In the later Privy Council decision of Singularis, Lord Collins considered re Phoenix:

'Proudman J... decided that the court had the power at common law to recognise a foreign administrator and to provide him with the same assistance as it was entitled to provide in a domestic insolvency..., 132

\footnotetext{
${ }^{128}$ Ibid, emphasis added.

${ }^{129}$ In re Phoenix Kapitaldienst GmbH; Schmitt v Deichmann and others [2012] EWHC 62.

${ }^{130}$ Ibid [4].

131 Ibid.

${ }^{132}$ Singularis Holdings Limited (Appellant) v PricewaterhouseCoopers (Respondent) [2014] UKPC 36 [97].
} 
Lord Collins directly contradicted the decision, noting that the 'decision [was] wrong because it involved an impermissible application of legislation by analogy.' 133 The notion of 'legislation by analogy' was also criticised by Auld JA in the Court of Appeal in Singularis as being tantamount to 'legislation from the bench. ${ }^{134}$ Lord Collins in Singularis further elaborated on the problems associated with 'legislation by analogy':

'In my view to apply insolvency legislation by analogy "as if" it applied, even though it does not actually apply, would go so far beyond the traditional judicial development of the common law as to be a plain usurpation of the legislative function.'

By contrast, it is interesting to consider how the African Farms decision granted a foreign liquidator powers that went beyond what would have been capable under Transvaal law - an act that may also be labelled 'legislation from the bench'. Recall that the Transvaal Court had 'no power to wind [African Farms] up in the Transvaal proceeding because the number of members had fallen below the minimum required to qualify it as a "company" for the purposes of the statutory power of winding up. ${ }^{135}$

Innes CJ pre-empted the objection that the court - in recognising the English liquidator would be 'doing by indirect means what the law has given us no power to do directly':

'The true test appears to me to be not whether we have the power to order a similar liquidation here, but whether our recognising the foreign liquidation is actually prohibited by any local rules; whether it is against the policy of our laws, or whether its consequences would be unfair to local creditors, or on other grounds undesirable... ${ }^{136}$

The inconsistency between the approaches outlined above was acknowledged by Lord Collins in Singularis, who expressed emphatically that 'the [African Farms] decision is certainly not authority for the proposition that local statutory law may be applied by analogy. 137

The idea of transplanting local legislation to different circumstances through the exercise of the inherent power was mentioned in the early Singaporean decision of Re China Underwriters. Chan Sek Keong JC emphasised that, in refusing to extend various statutory examination powers to a foreign company, '[t]he jurisdiction or power of the court in this respect was statutory in origin and had to be exercised within the ambit of legislative intent...

\footnotetext{
${ }^{133}$ Ibid [98].

${ }^{134}$ Re Singularis [2013] CA (Bda) 7 Civ [46].

${ }^{135}$ Singularis Holdings Limited (Appellant) v PricewaterhouseCoopers (Respondent) [2014] UKPC 36 [13] (per Lord Sumption).

${ }^{136}$ In re African Farms Ltd [1906] TS 373.

${ }^{137}$ Singularis Holdings Limited (Appellant) v PricewaterhouseCoopers (Respondent) [2014] UKPC 36 [56] (per Lord Collins).
} 
The Court thus had no jurisdiction to exercise such power in respect of the affairs of the winding up of a foreign company..., ${ }^{138}$

The inherent power of courts to provide assistance by granting a foreign administrator powers under domestic legislation is thus precarious. While earlier cases clearly view 'legislation by analogy' as no real impediment to assistance, Singularis has cast considerable doubt on the availability of this category of assistance.

\section{Assistance where there is no local ancillary liquidation proceeding}

An added layer of complexity arises in considering whether a court can rely on its inherent power to provide assistance where no local ancillary proceedings are on foot. It appears established that although ancillary liquidation proceedings represent one ground for the exercise of the inherent power, they are not a necessary ground. As noted by Lord Sumption in Singularis, '[t]he question what if any power the court has to assist a foreign liquidation without conducting an ancillary liquidation of its own, must depend on the nature of the assistance sought. ${ }^{139}$ This question has been considered by the Bermudian Courts, which rely extensively on the inherent power.

Failing to commence a local proceeding was found not to limit the exercise of the power in the Bermudian case of Re Founding Partners Global Fund Ltd. ${ }^{140}$ The case concerned the granting of an ex parte order in relation to a Caymanian-incorporated company pursuant to a letter of request issued by the Cayman Grand Court. The letter of request sought 'specific assistance by way of recognition of the status of the [Caymanian provisional liquidators], empowering them to get in and preserve any Bermudian assets and ordering a stay of proceedings against the Company. ${ }^{141}$ Importantly, ancillary proceedings had not been commenced in Bermuda.

The Bermudian court noted that 'this was possibly the first occasion upon which this Court had exercised its common law discretionary powers to cooperate with foreign insolvency courts by recognising and assisting the foreign proceeding without commencing ancillary liquidation. ${ }^{142}$

Furthermore, and by contrast with the views expressed in Singularis, the court was of the view that 'there seems now to be no doubt that this Court may at least empower a foreign insolvency representative to do all acts in Bermuda (in relation to Bermudian located assets

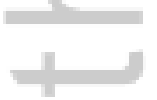

\footnotetext{
${ }^{138}$ Re China Underwriters Life and General Insurance Co Ltd [1998] SGHC 5, 40-1.

${ }^{139}$ Singularis Holdings Limited (Appellant) v PricewaterhouseCoopers (Respondent) [2014] UKPC 36 [11] (per Lord Sumption).

140 [2009] Bda LR 35.

${ }^{141}$ Ibid [4].

${ }^{142}$ Ibid [11].
} 
of the company in liquidation abroad) as could be performed by a local liquidator if ancillary proceedings were commenced here. ${ }^{143}$ Justice Kawaley saw Cambridge Gas as establishing:

'the important principle that the common law jurisdiction to assist a foreign insolvency court empowered the Manx Court to exercise any powers which were available in relation to an equivalent local proceeding; moreover, such assistance could be furnished without the need for ancillary winding-up proceedings to be commenced in the assisting forum. ${ }^{144}$

While the first part of the above extract is questionable in the light of the decision in Rubin and Singularis, the ability to provide assistance where no local ancillary liquidation proceeding has been commenced is potentially a significant strength of the inherent power, and was not expressly challenged in either Rubin or Singularis.

\section{Circumstances where the power has not been exercised}

The discussion in this Part examines three circumstances in which the inherent power has not been exercised: (1) where the power is invoked as a means to circumvent established doctrine; (2) where the relief sought is not available in either the foreign jurisdiction or the local jurisdiction; and (3) where the proper law of the claim is domestic law.

\section{A Enforcement of an in personam foreign judgment}

Following $H I H$, the case of Rubin v Eurofinance is regarded as the next significant decision to determine the scope of the inherent power. The case involved two appeals heard jointly, Rubin and New Cap. The material facts relevant to the appeals were summarised by Lord Collins, speaking for the majority:

'In Rubin a judgment of the US Federal Bankruptcy Court... in default of appearance for about [USD] 10m under State and Federal law in respect of fraudulent conveyances and transfers was enforced in England at common law. In New Cap a default judgment of the New South Wales Supreme Court... for about [USD] $8 \mathrm{~m}$ in respect of unfair preferences under Australian law was enforced under the Foreign Judgments (Reciprocal Enforcement) Act 1933, and, alternatively, pursuant to powers under section 426 of the Insolvency Act 1986. ${ }^{, 145}$

The key issue raised by the appeals was 'whether, and if so, in what circumstances, an order or judgment of a foreign court in proceedings to adjust or set aside prior transactions, e.g. preferences or transactions at an undervalue, will be recognised and enforced in England. ${ }^{146}$

\footnotetext{
${ }^{143}$ Ibid [11].

${ }^{144}$ Ibid [7].

${ }^{145}$ Rubin v Eurofinance SA [2012] UKSC 46 [2] (per Lord Collins).

${ }^{146}$ Ibid [1] (per Lord Collins).
} 
This involved considering whether insolvency - and the court's inherent power to provide assistance - could circumvent the 'Dicey Rule' applicable in this case. The rule, in short, describes the circumstances in which 'a court of a foreign country outside the United Kingdom has jurisdiction to give a judgment in personam capable of enforcement or recognition as against the person against whom it was given... ${ }^{147}$ The rule then provides a number of circumstances, two of which were significant in Rubin and involved 'submitting to the jurisdiction' of the relevant court.

In considering whether the inherent power could circumvent the Dicey Rule, Lord Collins stated the ultimate question in the following terms:

'As a matter of policy, should the court, in the interests of universality of insolvency proceedings, devise a rule for the recognition and enforcement of judgments in foreign insolvency proceedings which is more expansive, and more favourable to liquidators, trustees in bankruptcy, receivers and other officeholders, than the traditional common law rule embodied in the Dicey Rule, or should it be left to legislation preceded by any necessary consultation?' ${ }^{148}$

The majority held that the answer to this question was a resounding 'no'. The Dicey Rule, being well established, should not be departed from, especially because it was 'a matter for the legislature and not for judicial innovation.' The majority further reasoned that, 'the introduction of judge-made law extending the recognition and enforcement of foreign judgments would only be to the detriment of United Kingdom businesses without any corresponding benefit. ${ }^{149}$ Cambridge Gas was 'wrongly decided' because 'there had been no submission to the jurisdiction of the court in New York [and] Cambridge Gas was not subject to the personal jurisdiction of the US Bankruptcy Court... There was... no basis for the recognition of the order.' 150

One view of Rubin is that it has stymied the inherent power and its potential application. Others have pointed out that Rubin was 'fundamentally about the recognition of judgments ${ }^{151}$ and not about the application of the inherent power.

While Rubin did acknowledge a number of established categories of assistance, it has nevertheless attracted criticism for its lack of clarity surrounding the boundaries of the inherent power:

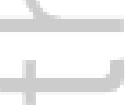

${ }^{147}$ Ibid [7].

${ }^{148}$ Ibid [91].

${ }^{149}$ Ibid [129-130].

${ }^{150}$ Ibid [132] (per Lord Collins).

${ }^{151}$ Craig Montgomery, 'Keep Calm and Don't Submit - the Supreme Court has its say on Recognition of Foreign Insolvency Proceedings’ [2013] 26(2) Insolvency Intelligence 29. 
'There is no explanation in Rubin of the boundaries between the types of assistance which are available at common law and those which are not. The implication of Lord Collins' approach is that it depends whether the courts have previously granted the relevant form of relief. But it does not seem to be a satisfactory explanation to say that those forms of assistance which the courts have previously granted are available, whereas any other forms of assistance are not. That approach would leave the common law frozen in aspic, but moreover fails to provide any principled reason or rationale as to why it is that certain forms of assistance, but not others, are available. $^{152}$

What is clear from Rubin is that the Dicey Rule, as it relates to the enforcement of in personam judgments, will not be subordinated to the inherent power.

\section{B Providing relief that is not available in either the foreign or local jurisdiction}

The most recent - and possibly significant - authority on the inherent power is the decision of the Privy Council in Singularis Holdings Limited $v$ PricewaterhouseCoopers. The case concerned a joint appeal on related questions of law. The essence of the two cases have been summarised by Tom Smith QC in the following terms:

'In the Singularis case the question was whether the Bermudan courts had power to apply statutory provisions, which by their terms were applicable in the case of a Bermudan liquidation and provided for the production of information and documents to the liquidator, in support of a Cayman liquidation. In the Saad case the question was whether it was appropriate for the Bermudan court to have made a winding-up order in respect of a Cayman company for the purpose of making Bermudan statutory provisions providing for the production of documents available, and consideration was given to the circumstances in which a subsequent challenge to the winding-up order could be made. ${ }^{153}$

Lord Sumption affirmed the existence of a "power at common law to assist a foreign court of insolvency jurisdiction by ordering the production of information in oral or documentary form which is necessary for the administration of a foreign winding up.' But with a word of caution, Lord Sumption further added that '[i]n recognising the existence of such a power, the Board would not wish to encourage the promiscuous creation of other common law powers to compel the production of information. ${ }^{154}$

\footnotetext{
152 Tom Smith QC, 'Recognition of Foreign Corporate Insolvency Proceedings at Common Law' in Richard Sheldon QC (ed), Cross-Border Insolvency (4th edition, Bloomsbury Professional, 2015) 6.61.

${ }^{153}$ Ibid 6.62 .

${ }^{154}$ Singularis Holdings Limited (Appellant) v PricewaterhouseCoopers (Respondent) [2014] UKPC 36 [25] (per Lord Sumption). Lord Sumption expressed the view in [23] that although the present case was not a Norwich Pharmacal case, under which disclosure orders could be made against innocent third parties that hold information relating to wrongdoing, Norwich Pharmacal illustrated 'the capacity of the common law to develop
} 
The power - as it was applied to compel the production of information - was subject to various restrictions according to Lord Sumption. In particular, it is a power of assistance that is not 'available to enable [the court] to do something which they could not do even under the law by which they were appointed'. Further, it is available 'only when it is necessary for the performance of the office-holder's functions' and 'is not available for purposes which are properly the subject of other schemes for the compulsory provision of information. ${ }^{, 155}$

Lord Collins also sought to lay out propositions regarding the power to assist:

'In my judgment the answer to the present appeal is to be found in the following propositions. First, there is a principle of the common law that the court has the power to recognise and grant assistance to foreign insolvency proceedings. Second, that power is primarily exercised through the existing powers of the court. Third, those powers can be extended or developed from existing powers through the traditional judicial law-making techniques of the common law. Fourth, the very limited application of legislation by analogy does not allow the judiciary to extend the scope of insolvency legislation to cases where it does not apply. Fifth, in consequence, those powers do not extend to the application, by analogy "as if" the foreign insolvency were a domestic insolvency, of statutory powers which do not actually apply in the instant case. ${ }^{156}$

Similar limitations were also identified by Lord Mance - the 'domestic court does not have power to assist a foreign court by doing anything which it could properly have done in a domestic insolvency; and it cannot acquire jurisdiction by virtue of any such power. ${ }^{, 157}$

It has been suggested by Richard Sheldon QC that the result in Singularis means that "common law assistance may be given, but only to provide relief which is available both in the officeholder's own (foreign) jurisdiction and under the domestic common law of the country in which he seeks assistance. ${ }^{158}$

\section{Where the proper law of the claim is domestic law}

Where assistance is sought by a foreign court via a letter of request, a local court may refuse to provide assistance if it is clear that the proper law of the claim is domestic law and the local jurisdiction would be the more appropriate forum. This was considered in the Australian

a power in the court to compel the production of information when this is necessary to give effect to a recognised legal principle'. Lord Collins agreed with this view in [111].

155 Ibid.

${ }^{156}$ Ibid [38] (per Lord Collins). Emphasis added.

${ }^{157}$ Ibid [134] (per Lord Mance).

${ }^{158}$ Richard Sheldon QC (ed), Cross-Border Insolvency (4th edition, Bloomsbury Professional, 2015) 1.5. 
case of Rolfe $v$ Transworld Marine Agency Co. ${ }^{159}$ The proceeding involved money allegedly due under an agreement:

'to pay commission in relation to the recovery of monies due to the respondent company under maritime claims on the proceeds of sale of two ships. The applicant sought orders for payment out of a fund representing the proceeds of sale. The Commercial Court for the District of Antwerp had issued letters of request to the Federal Court at the request of the Belgian trustees in bankruptcy of the respondent company, seeking that the present proceedings be stayed and the fund representing the proceeds of sale be remitted to the trustees.' 160

Section 581 of the Corporations Act 2001 relevantly provides:

'Courts to act in aid of each other

(1) All courts having jurisdiction in matters arising under this Act, the Judges of those courts and the officers of, or under the control of, those courts must severally act in aid of, and be auxiliary to, each other in all external administration matters.

(2) In all external administration matters, the Court:

(a) must act in aid of, and be auxiliary to, the courts of:

(i) external Territories; and

(ii) States that are not in this jurisdiction; and

(iii) prescribed countries;

that have jurisdiction in external administration matters; and

(b) may act in aid of, and be auxiliary to, the courts of other countries that have jurisdiction in external administration matters.'

Belgium was not a 'prescribed country' and assistance was instead sought on the discretionary basis of s 581(2)(b). The respondent argued that 'the discretion should be exercised in accordance with accepted principles of comity and the request granted.' 161

Justice Tamberlin in Rolfe ultimately refused to recognise the Belgian court's letter of request because, inter alia, the proper law governing the applicant's claim was Australian law:

'[T]he funds were recovered in Australia; the collection work was carried out in Australia; and the claim on the proceeds was decided according to Australian law... There are no substantial countervailing connections with Belgium apart from the evidence of its incorporation and bankruptcy. ${ }^{, 162}$

\footnotetext{
${ }^{159}$ Rolfe v Transworld Marine Agency Co Nv (1998) 28 ACSR 117.

${ }^{160}$ Ibid 118

161 Ibid 134

${ }^{162}$ Ibid.
} 
It is also conceivable that a court approached by a foreign court or representative for assistance may refuse to grant assistance where it is clear that the foreign court proceeding should, in actual fact, be regarded as the ancillary proceeding. This point has been made by Smart:

'Merely because incorporation has taken place in a foreign country does not necessarily mean that [a]... liquidation must be ancillary or auxiliary. For example, a company may be incorporated in Panama yet do all its business and have all its creditors and corporators in England.' 163

\section{Analysing the continuing utility of the inherent power}

After considering the nature of the power, the factors that influence the exercise of the power, and the circumstances under which the power has or has not been exercised, it is now expedient to examine the continuing utility of the power.

First, a brief outline of the current balance of authority under English law concerning the scope and application of the power is provided. Secondly, arguments both in favour and against affording greater prominence to the power are considered. Finally, suggestions are made regarding the future direction of the power and its development.

\section{A The current balance of authority}

The current balance of authority under English law appears to indicate the following:

1. Modified universalism is recognised in the common law in most jurisdictions.

2. The inherent power can be divided into established categories of assistance. For example, it is well established that a court may remit assets and order a stay of local proceedings where the foreign principal liquidation will be carried out on the basis of a pari passu distribution.

3. The recognised categories of assistance are capable of development in accordance with the typical organic development of the common law. This development is likely to be 'incremental' rather than 'extreme' (as seen in Lord Hoffmann's approach in $H I H$ ).

4. The exercise of the power will always be subject to the public policy considerations of the assisting court.

5. It is not always necessary that an ancillary liquidation be commenced before requesting assistance from a foreign court.

6. Following Singularis, it would appear that the exercise of the inherent power will be subject to the substantive law of the local jurisdiction, and cannot be exercised

163 P Smart, 'International Insolvency: Ancillary Winding up and the Foreign Corporation' (1990) 39 International and Comparative Law Quarterly 827, 831. 
unless the type of assistance would be available both locally and in the foreign jurisdiction.

7. Where there is local legislation that confers powers on administrators, courts will be reluctant to legislate from the bench and grant the same powers to a foreign administrator in circumstances where the powers are not available in the foreign jurisdiction.

8. The prevalent view - contrary to the view of Lord Hoffmann in $H I H$ and Cambridge Gas - is that common law courts are in no way able to 'disapply' the local statutory regime.

\section{B The benefits and disadvantages of recognising the power}

\section{Arguments in favour of retaining the inherent power as an available gateway}

Flexibility

A clear argument in favour of continuing to recognise the inherent power is its fundamental flexibility. Like the common law, it has shown itself capable of evolution, and capable of adapting to different circumstances. ${ }^{164}$ In an area as fast-paced, dynamic and unpredictable as CBI law, rigidity may prove an obstacle to reaching the 'best' outcome.

The inherent power may also prove 'flexible' in achieving the various policy outcomes of government. It is clear that legislatures often create multiple gateways through which courts can address CBIs - Australia and the United Kingdom are good examples. Where it is clear the legislature has not intended to create an exclusive gateway, the inherent power can exist alongside other gateways. These 'other' gateways are very often geared toward achieving certain policy outcomes - for example, the existence of the preferential regimes under s 581 of the Corporations Act 2001 in Australia and s 426 of the Insolvency Act 1986 in the UK is designed to achieve favourable outcomes for prescribed countries who are recognised for historical reasons. The Model Law similarly provides for countries to exclude certain entities from its operation. Australia, for example, excludes Authorised Deposit-taking Institutions, General Insurers and Life Insurance Companies. ${ }^{165}$ The inherent power may thus form part of the judicial toolkit through which government policy objectives may be achieved.

Closely related to the flexibility argument is the argument in favour of innovation. 'Commercial necessity' has often been cited as a catalyst for judicial innovation. In Credit Suisse Fides Trust v Cuoghi, ${ }^{166}$ Millett LJ noted that commercial necessity has 'encouraged

\footnotetext{
${ }^{164}$ While this typically stands in contrast to statute, it must be noted that much of the legislation governing CBIs is inherently flexible and leaves considerable judicial discretion.

165 See Cross-Border Insolvency Act 2008 (Cth) s 9; Cross-Border Insolvency Regulations 2008 (Cth) r 4 'Schedule 1'. The exclusions in the US are far broader. See S Chandra Mohan, 'Cross-border Insolvency Problems: Is the UNCITRAL Model Law the Answer?' (2012) 21(3) International Insolvency Review 199, 213. ${ }^{166}$ [1998] QB 818.
} 
national courts to provide assistance to each other without waiting for such co-operation to be sanctioned by international convention. ${ }^{167}$ Given that an international insolvency convention is a very remote prospect, judicial innovation - within appropriate boundaries - has the potential to stimulate CBI law reform, particularly in the area of judicial assistance. The continued existence of the inherent power would be desirable to facilitate this innovation. Lord Collins in Singularis has indicated that he would be broadly supportive of innovation 'provided that the development is measured and supports recognised principle.' 168

Potential for principled development

Few would argue that, where possible, assistance in CBI law should develop incrementally from established categories. Prima facie, one might assume that the way to achieve a harmonious approach between jurisdictions would be through the implementation of the Model Law. Indeed, the Model Law has recently seen an increase in its adoption. As of 17 November 2015, 40 States in a total of 41 jurisdictions had adopted the Model Law. ${ }^{169}$ Yet behind this apparent convergence is the reality that nearly all jurisdictions have implemented the Model Law in a manner that varies from the original text. For example, in Canada, over $30 \%$ of the Articles have been omitted or partially omitted from the local statute. ${ }^{170}$ The differences in implementation are exacerbated in each jurisdiction by the manner in which provisions are interpreted. ${ }^{171}$ Thus, what has resulted is not one 'Model Law', but a complex set of local permutations that create layered complexity for courts and practitioners.

If, as the courts have suggested, the power exists and is being capable of developed incrementally, there is hope yet that the future beyond Singularis may bring some much needed clarity. If it is accepted that the inherent power has been in a state of 'arrested development' as suggested by Lord Hoffmann in Cambridge Gas, it may just be a matter of

\footnotetext{
${ }^{167}$ Credit Suisse Fides Trust v Cuoghi [1998] QB 818, 827.

${ }_{168}$ Singularis Holdings Limited (Appellant) v PricewaterhouseCoopers (Respondent) [2014] UKPC 36 [115].

169 UNCITRAL, 'UNCITRAL Model Law on Cross-Border Insolvency (1997) - Status', available at: <http://www.uncitral.org/uncitral/en/uncitral_texts/insolvency/1997Model_status.html>. The Model Law Guide to Enactment notes that '[i]n addition to the 36 States members of UNCITRAL, representatives of 40 observer States and 13 international organizations participated in the deliberations of the Commission and the Working Group': UNCITRAL, 'UNCITRAL Model Law on Cross-Border Insolvency with Guide to Enactment and Interpretation' (2014) 23 [16].

${ }^{170}$ Bruce Leonard, 'Canada' in Bruce Leonard (ed), Getting the Deal Through: Restructuring and Insolvency 2015,95 .

${ }^{171}$ It is well beyond the scope of this article to consider Model Law interpretation in any detail. For articles considering issues surrounding interpretation, see Sandeep Gopalan and Michael Guihot, 'Recognition and Enforcement in Cross-Border Insolvency Law: A Proposal for Judicial Gap-Filling' (Deakin Law School Legal Studies Research Paper No. 15-02, 2015); Morshed Mannan, 'The Prospects and Challenges of Adopting the UNCITRAL Model Law on Cross-Border Insolvency in South Asia' (Bangladesh, India and Pakistan) (27 July 2015); Jennifer Delvin, 'The UNCITRAL Model Law on Cross-Border Insolvency and its impact on maritime creditors' (2010) 21 Journal of Banking and Finance Law and Practice 95; Elizabeth Buckel, 'Curbing Comity: The Increasingly Expansive Public Policy Exception of Chapter 15' (2013) 44 Georgetown Journal of International Law 1281.
} 
time before more cogent principles emerge. This is by no means a suggestion that it is the best way of developing principles of CBI judicial assistance - merely an option that need to be given due weight.

Arguments against retaining the inherent power as an available gateway

(a) Uncertainty

Perhaps it is too optimistic to suggest that the inherent power can develop with any more clarity than was achieved in either HIH, Rubin or Singularis. Each decision and each jurisdiction has, in its own way, compounded the uncertainty surrounding the boundaries of the inherent power. This uncertainty may reflect a fundamental disagreement over the essential nature of insolvency proceedings.

Lord Sumption in Singularis described Cambridge Gas as marking 'the furthest that the common law courts have gone in developing the common law powers of the court to assist a foreign liquidation.' ${ }^{172}$ This is correct if by 'furthest' Lord Sumption is suggesting 'least restricted.' But even if one accepts that Singularis was a necessary refinement of the inherent power, Singularis arguably raises as many questions as it resolves.

If the inherent power is capable of incremental development, what are the criteria that should inform this development? There were different opinions on this point in Singularis, but neither the majority nor the minority indicated the extent of such development. Lord Neuberger was the most conservative on this point. His Honour found that courts should avoid 'seeking to lay down general principles which it is not necessary to determine, particularly when those principles involve extending the court's powers in a way which may have substantial ramifications. ${ }^{173}$ However, this does little to assist jurisdictions that continue to rely on the inherent power in the absence of statute, and most acutely affects those jurisdictions that rely on the Privy Council as their final Court of Appeal. At present, except for the various limitations espoused in Singularis, there is no way of knowing with any certainty where the limits should lie.

Other areas of concern are the charges of 'legislating from the bench' and 'disapplying' the local statutory regime to deprive creditors of their statutory rights. There is a lack of clarity on what amounts to a judge 'usurping' the role of the legislature. Similarly, the notion of applying 'legislation by analogy', while widely chided, does not assist in understanding the limits of the inherent power. What is clear is that CBI law is fraught with tension surrounding the appropriate role of the judiciary and, consequently, the scope of the inherent power.

\footnotetext{
${ }^{172}$ Singularis Holdings Limited (Appellant) v PricewaterhouseCoopers (Respondent) [2014] UKPC 36 [18] (per Lord Sumption).

${ }^{173}$ Ibid [155].
} 
In view of this uncertainty, some might argue that the Model Law or equivalent legislation, acknowledging that it is nevertheless imperfect, should instead be relied on as the exclusive gateway for providing judicial assistance. This would avoid a misapplication of the inherent power in future CBI cases, although similar issues may still arise when discretionary relief is sought under the Model Law.

(b) Political sensitivities and the role of courts

The politically sensitive nature of insolvency law is an inescapable reality. A State's bankruptcy laws 'reflect its distributional value judgments', and a State will have a natural inclination to 'prefer... its own bankruptcy law to that of any other state.' Furthermore:

'If foreign bankruptcy law[s] [apply] to assets located in a state's jurisdiction, a state suffers the incommensurable costs of relinquishing the preferred distributional outcomes of its own bankruptcy law. ${ }^{174}$

Courts are clearly aware of the value judgments embedded in an insolvency regime, and it is hardly a surprise that they should be reluctant to disapply, or avoid applying, that regime. Distributional priorities in liquidation require 'winners' and 'losers' to be chosen. It stands to reason that significant deviation from that regime - without good reason - should be avoided.

The inherent power tends to tread very closely along the boundaries of what courts regard as acceptable. This explains why attempts to provide judicial assistance to foreign courts or representatives have occasionally been characterised as 'usurping' the role of the legislature. If the primary consideration for courts is to ensure they do not upset the status quo arrangements, then Lord Neuberger's approach would seem warranted:

'Judges should not be creating the [power]... when one considers the extent of domestic statutory law and international convention law in the area of international insolvency...

In this highly legislated area, I consider that the power which is said to arise in this case is one which should be bestowed on the court by the legislature, and not arrogated to the court of its own motion. ${ }^{175}$

Thus, it could be argued that the courts should leave any extension of common law judicial assistance to the legislature. This will ensure that the fundamental values inherent in the local insolvency regime are not offended. It also acknowledges that the legislature has in many instances been heavily involved in establishing CBI regimes.

\footnotetext{
174 Sefa Franken, 'Cross-Border Insolvency Law: A Comparative Institutional Analysis' (2014) 34 Oxford Journal of Legal Studies 97, 109.

${ }^{175}$ Singularis Holdings Limited (Appellant) v Pricewaterhouse Coopers (Respondent) [2014] UKPC 36 [161]. A counterpoint to the suggestion that CBI is a 'highly legislated area', and that the legislature has thus taken the reigns, is the clear parliamentary intention to create multiple gateways of facilitating judicial assistance.
} 


\section{First principles and the way forward}

Speaking with respect to the entire corpus of judicial assistance cases, Briggs notes:

'The fact that each decision has only added to the confusion reflects the deeply divergent points of view from which the issues are appreciated. A return to first principles will be impossible until there is agreement as to what the principles are; and any such agreement seems well out of judicial reach., ${ }^{176}$

As intimated above, the fundamental disagreements between HIH, Rubin and Singularis may not actually directly relate to the scope and application of the inherent power at all. The real disagreements may instead relate to fundamental questions such as the relationship between the judiciary and the legislature, the role of judges in granting assistance to foreign insolvency proceedings and the importance of principles such as pari passu distribution in insolvency.

The answers to these questions may depend on an assessment of the dictates of 'modified universalism.' This is not to say that any attempt at identifying cogent first principles is otiose. For example, at a bare minimum it is uncontroversial to suggest that insolvency proceedings should proceed in a manner that (a) promotes certainty; (b) minimises destruction in value; (c) gives effect to the legitimate expectations of creditors; and (d) where possible, adheres to the principle of pari passu.

Bearing these four objectives in mind, how should the current framework be modified to achieve these objectives? Below is a modest attempt at identifying the principles for answering the question of whether or not to extend assistance through the use of the inherent power:

1. To reflect the universal nature of insolvency proceedings and the desirability of 'modified universalism', courts should provide active assistance to foreign representatives and courts where possible. ${ }^{177}$

2. Where legislation expressly provides how courts should provide assistance to foreign representatives or courts, and it is clear that the legislation is the sole gateway for providing assistance, then assistance must be provided in accordance with the legislation. ${ }^{178}$

\footnotetext{
${ }^{176}$ Adrian Briggs, 'Judicial Assistance still in need of Judicial Assistance' [2015] Lloyd's Maritime and Commercial Law Quarterly 179, 179.

177 'Modified universalism' is accepted, or recognised as being desirable, in most common law jurisdictions. This point is unlikely to be controversial, given that the court in Singularis accepted modified universalism. The need to provide 'active assistance' upon recognition was established in African Farms.

${ }^{178}$ See Bear Stearns. Courts are clearly under an obligation to apply statute where its meaning is unequivocal.
} 
3. Where there are multiple gateways for providing assistance, parties should be free to choose the most advantageous gateway. The fact that one gateway might apply in the same circumstances as the inherent power should not be taken to limit the exercise of the inherent power. ${ }^{179}$

4. Where a party seeks to rely on a court's inherent power to provide assistance - for example, where a foreign liquidator applies directly to the court seeking a stay or an order to remit assets - assistance may be provided if this falls under a recognised category of assistance under case law and there is nothing objectionable about the assistance on the grounds of public policy. ${ }^{180}$

5. Where there is no recognised category of assistance under case law, a court may still be able to provide assistance and recognise a new category of assistance in a manner that is consistent with the incremental development of the common law, even if it involves applying the local statutory law by analogy, so long as the following factors are present:

a. There is sufficient similarity between the assisting court's local insolvency regime and the foreign regime, such that any relief sought would not diverge significantly from the relief generally available under the local regime or the relief generally available under the foreign regime;

b. It would not be contrary to public policy or prohibited by local laws;

c. It would, viewing the class of creditors as a whole, assist with the orderly distribution of assets under liquidation and in accordance with the principle of pari passu distribution;

d. It would be fair to, and would give effect to the legitimate expectations of, all creditors; and

e. It would be desirable for the purpose of promoting and encouraging comity with the foreign court.

\section{Conclusion}

The inherent power has troubled courts since Lord Hoffmann's dicta in Cambridge Gas. Lord Neuberger saw subsequent developments in Rubin resulting in the 'extreme version' of the principle of universality 'effectively disappear[ing]'. Yet his Honour went on to remark that 'as with the Cheshire Cat, the principle's deceptively benevolent smile still appears to linger.' 181

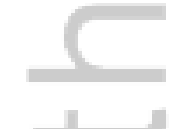

\footnotetext{
${ }^{179}$ See McGrath $v$ Riddell. It is clear that in both England and Australia, Parliament has intended for multiple gateways to exist. Considered in light of Lord Scott's comments in HIH, there may be objections to this suggestion on the basis that ignoring the statutory scheme and proceeding on the basis of the inherent power is tantamount to 'disapplying' the statutory scheme.

${ }^{180}$ This is consistent with Singularis.

181 Singularis Holdings Limited (Appellant) v PricewaterhouseCoopers (Respondent) [2014] UKPC 36 [157] (per Lord Neuberger).
} 
Notwithstanding the current favoured incremental approach, this article has shown how the inherent power has been shaped and influenced by a variety of factors. The specific examples of the exercise of the power are instructive, as are the examples where courts have refused to exercise the power. The balance of authority clearly shows that the inherent power exists in many jurisdictions, that it applies in relevant cases, and that it can be developed incrementally. Equally, the courts have accepted the principle of 'modified universalism' without exception, albeit with varying degrees of enthusiasm.

The benefits and disadvantages of continuing to recognise - and extend - the power have been considered. While there are arguments on both sides, the real disagreement, it is suggested, arises from fundamental differences about underlying values and ultimate outcomes. Notwithstanding these differences, which will inevitably shape the exercise of the judicial assistance power, it may be possible to agree on a number of principles that inform the application of the inherent power and its future development.

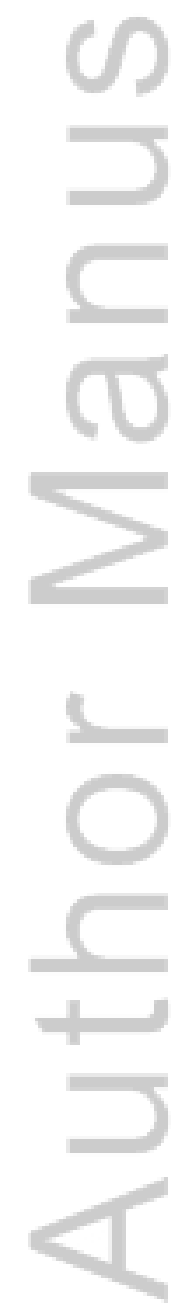

This article is protected by copyright. All rights reserved. 


\section{University Library}

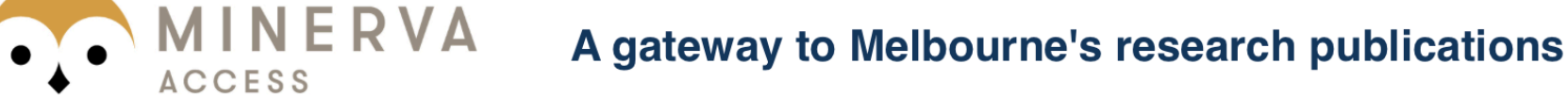

Minerva Access is the Institutional Repository of The University of Melbourne

Author/s:

Godwin, A;Howse, T;Ramsay, I

Title:

The Inherent Power of Common Law Courts to Provide Assistance in Cross-Border Insolvencies: From Comity to Complexity

Date:

2017-03-01

Citation:

Godwin, A., Howse, T. \& Ramsay, I. (2017). The Inherent Power of Common Law Courts to Provide Assistance in Cross-Border Insolvencies: From Comity to Complexity. INTERNATIONAL INSOLVENCY REVIEW, 26 (1), pp.5-39. https://doi.org/10.1002/iir.1267.

Persistent Link:

http://hdl.handle.net/11343/292567 